\title{
Z refleksji mariologicznej doby reformacji. Trzy nauki na dzień Nawiedzenia Maryi Panny: Rej — Wujek — Skarga
}

Ważkie pole kontrowersji wyznaniowej XVI wieku, refleksja o Matce Bożej i jej czci, pozostaje zbadane niewystarczająco tak, że wciąż funkcjonują stereotypy, które utrudniają rozpoznanie zarówno reformacyjnej, jak i kontrreformacyjnej teologii i pobożności: wyobrażenie o radykalnej odmienności protestanckiej i katolickiej refleksji maryjnej prowadzi do sądów o ewangelickim negowaniu godności Matki Bożej czy o katolickim zastąpieniu przez Jej kult orientacji chrystocentrycznej, czyli istotnie chrześcijańskiej. Ponieważ szczególnym przejawem świadomości teologicznej, a zarazem źródłem popularnych wyobrażeń teologicznych jest kaznodziejstwo, studium refleksji mariologicznej nie może obejść się bez analizy tekstów trzech najważniejszych, bo najbardziej popularnych autorów kazań w XVI wieku: ewangelickiego postyllografa Mikołaja Reja oraz dwóch kaznodziejów katolickich: biblisty Jakuba Wujka SI i hagiografa Piotra Skargi SJ.

Choć wśród kazań Reja można odnaleźć wiele myśli o Matce Bożej, zwłaszcza w komentarzach do Ewangelii dzieciństwa Jezusa, Nagłowiczanin napisał jedno kazanie, które można określić jako maryjne ${ }^{1}$. Ta

\footnotetext{
1 Określenie „mariologiczne” mogłoby być użyte tylko w przybliżeniu, skoro doktryny protestanckie nie zawierają specjalnej dziedziny teologii, zwanej w katolicyzmie mariologią, a ich refleksja o Matce Bożej jest aspektem chrystologii. Por. J. Gross, Stosunek Kościota ewangelicko-augsburskiego do kultu Maryi Panny, w: Nosicielka Ducha - Pneumatofora. Materiaty z kongresu mariologicznego. Jasna Góra. 18-23 sierpnia 1996 r., red. nauk. J. Wojtkowski, S. C. Napiórkowski, Lublin 1998, s. 101; W. Nast, Przez Jezusa do Maryi w tradycji ewangelickiej, w: Przez Jezusa do Maryi. Materiaty
} 
nauka na święto Nawiedzenia Panny Maryi zawiera jednak dość pełną wypowiedź o Matce Boskiej, odnosząc się do wszystkich katolickich dogmatów mariologicznych oraz innych świąt maryjnych. Wujek i Skarga napisali oczywiście więcej kazań maryjnych, skoncentrowanych na kolejnych maryjnych świętach. I oni jednak w tekstach o Nawiedzeniu odnoszą się do innych prawd i przywilejów maryjnych, można więc, gwoli ukonkretnienia analizy, na nich poprzestać, zmierzając w zestawieniu z Rejem do rozpoznania relacji myśli trzech kaznodziejów XVI stulecia. Niech nauka na święto Nawiedzenia Maryi Panny stanie się soczewką, w której zobaczymy refleksję maryjną Reja, Wujka i Skargi oraz ich powiązania.

Kazanie na dzień Nawiedzenia Panny Maryi Reja wchodzi w skład dzieła Świętych stow a spraw Pańskich, ktore tu sprawowat Pan a zbawiciel nasz na tym świecie jako prawy Bog, będąc w cztowieczeństwie swoim, Kronika albo Postylla, polskim jezykiem a prostym wyktadem, też dla prostakow krotce uczyniona. Ukazało się ono za życia autora trzykrotnie, zawsze z datą wydania 1556, jednak w istocie w 1557, 1560 i 1566 roku; w kolejnych edycjach Rej modyfikował je stylistycznie i treściowo. W tekście interesującego nas kazania wprowadził zmiany między pierwszym i drugim wydaniem, są to jednak poprawki, które nie wpływają na wymowę teologiczną, choć czasem podkreślają aspekt polemiczny wobec dogmatyki i pobożności katolickiej².

z sympozjum mariologicznego zorganizowanego przez Polskie Towarzystwo Mariologiczne. Licheń, 26-27 października 2001 roku, red. nauk. S. C. Napiórkowski, K. Pek, Częstochowa-Licheń, s. 204.

2 Zob. M. M. Kacprzak, „Mariologia” XVI-wiecznego kaznodziei protestanckiego. Nauka na dzień Nawiedzenia Panny Maryi z Postylli Mikotaja Reja, „Zeszyty Naukowe Szkoły Wyższej Przymierza Rodzin. Seria polonistyczna”, nr 1, w druku; K. Górski, Pochodzenie tekstu, w: Mikołaj Rej, Postylla, cz. I, oprac. K. Górski, W. Kuraszkiewicz (wstęp edytorski, opracowanie językowe, objaśnienia), I. Rostkowska (bibliografia wydań), L. Zdancewiczowa, Z. Zierhofferowa (porównanie wydań), J. Klimaszewska (komentarz etnograficzny), Wrocław-Warszawa-Kraków, MCMLXV („Biblioteka Pisarzów Polskich”, seria B, nr 14), s. 7; Wykazy różnic tekstowych, w: ibidem; K. Kolbuszewski, Postyllografja polska XVI i XVII wieku, Kraków 1921, s. 65, 69-70, 79; J. Kallenbach, O Postylli Reja, w: Z wieku Mikotaja Reja. Ksiega jubileuszowa 1505 1905, Warszawa 1905, s. 109-113; J. T. Maciuszko, Postylla, w: Id., Mikotaj Rej. Zapomniany teolog ewangelicki z XVI w., Warszawa 2002, s. 363, 365; A. Brückner, Mikotaj Rej. Cztowiek i dzieto, Lwów 1922, s. 42. 
Jakub Wujek zamieścił kazania na dzień Nawiedzenia w obydwu postyllach. W obszernej Postilla catholica, to jest Kazania na kożda niedzielę i na kożde święto przez caty rok homilia Na dzień Nawiedzenia Panny Maryjej znalazła się w części drugiej, wydanej w 1573 roku, „w ktorej sie zawierają kazania na święta Panny Maryjej, Apostołow, Męczennikow i innych świętych, ktorych święta Kościoł zwykł obchodzić”. W skrócie dzieła z 1579-1580 roku kazanie na Nawiedzenie, pod tym samym tytułem, umieszczono także w części drugiej: Postilla katolicka mniejsza, ktora ma w sobie kazania na święta Panny Maryjej, apostotow, męczennikow, wyznawcow, panien i wdow świętych, ktorych święta Kościot zwykt obchodzić przez caty rok wedtug nauki Kościota świętego chrześcijańskiego powszechnego. To dwa różne teksty, przy czym odmienność nie wynika tylko ze skrócenia. W sferze inwencyjnej różnice rzeczywiście polegają na tym, że kazanie pierwsze jest bogatsze treściowo, w sferze wypowiedzenia — fragmenty tekstów są miejscami bardzo zbliżone albo wręcz tożsame, jednak dyspozycja jest różna. Rozdział materiału i kompozycja kazań zostały opracowane osobno dla obydwu tekstów. Dla porządku dodajmy, że w Postylli... mniejszej... zamieścił Wujek także nieoryginalne, odmienne stylistycznie i obrazowo Na święto Nawiedzenia Panny Maryjej kazanie drugie, zebrane z Bernarda świętego.

Piotr Skarga także jest autorem dwóch kazań na święto Nawiedzenia. Pierwsze - Na dzień Nawiedzenia Elżbiety od Matki Bożej kazanie krótkie — znajduje się w bestsellerowym dziele hagiograficznym Żywoty swiętych Starego i Nowego Zakonu na każdy dzień przez caty rok, wybrane z poważnych pisarzów i doktorów kościelnych, do których przydane sq niektóre duchowne obroki i nauki przeciwko kacerstwom, przytem kazania krótkie na te święta, które pewny dzień $w$ miesiącu maja, wydanym pierwszy raz w Wilnie w 1579 roku i jeszcze co najmniej siedmiokrotnie za życia autora, po wydanie krakowskie z 1610 roku. Po raz drugi napisał Skarga kazanie Na dzień Nawiedzenia Matki Bożej do zbioru homiletycznego Kazania na niedziele i święta catego roku z 1595 roku. To dwa różne utwory, choć o niemal tożsamej sferze inventio, w zasadzie niezależne w sferze wypowiedzenia i niewątpliwie różne w sferze dispositio. Całkowita odmienność kompozycyjna wiąże się z odmiennością gatunkową — tekst pierwszy to hagiografia w formie kazania, drugi to homilia. Warto zauważyć, że obydwa kazania są oryginalne — choć najpopularniejsze dzieło Skargi, Żywoty świętych..., powstało na polece- 
nie adaptacji łacińskiego kompendium Laurentiusa Suriusa De probatis Sanctorum Historiis i oparło się na wielu źródłach, jednak interesujące nas kazanie nie jest wtórne. Autor opracowania warsztatu Żywotów... i nowej typologii ich źródeł stwierdził, że Skarga w przypadku wielu kazań „de tempore” o życiu Chrystusa i Maryi zastępuje wersję Suriusa nowym tekstem ${ }^{3}$; tak jest i w kazaniu na święto Nawiedzenia 2 lipca, dla którego sam Skarga nie wskazuje źródła (tekstu zasadniczo nie przekształca do editio ultima z 1610 roku $)^{4}$.

Wobec faktu, że interesuje nas sfera ideowa utworów, w niniejszym artykule zajmiemy się (oprócz tekstu Reja) tymi kazaniami Wujka i Skargi, które wchodziły w skład zbiorów bardziej rozpowszechnionych i znaczących dla ówczesnej kultury — Postylli... mniejszej... Wujka i Żywotów swiętych... Skargi. Refleksje o utworach z „dużej” Postylli... i Kazań na niedziele i święta... uzupełnią nasze rozważania tam, gdzie przynoszą one ważne treści, nowe w stosunku do swych kazań „siostrzanych”.

\section{Mikołaj Rej}

Rej w swym kazaniu na kilka sposobów wprowadza do lektury i interpretacji perykopy (Łk 1, 39-56). W tytule streszcza ją jako naukę „Przeciwko hardości białych głow" ${ }^{-}$- karcąca pychę kobiet, sugerując adresowanie do konkretnego stanu i związane $\mathrm{z}$ nim zagadnienia etyczne. Cytuje Biblię - nie incipit perykopy, ale drugi werset jej ważnej części, Magnificat (Łk 1, 47), zapowiadając niejako, że to hymn Maryi będzie pozostawał w centrum kazania. Streszczenie na marginaliach: „Nadobna nauka, jako sie mamy sprawować w pociechach swych, nam z matki człowieczeństwa Pańskiego zostawiona, i jakich przykładow sie z niej ine białe głowy uczyć mają" wskazuje, że spośród czterech tradycyjnie

$3 \quad$ Zob. A. Ceccherelli, Od Suriusa do Skargi. Studium porównawcze o Żywotach świętych, przeł. M. Niewójt, Izabelin 2003, s. 80-81.

4 Zob. ibidem, s. 215, 259.

5 Tekst trzeciego wydania Postylli Reja cytuję według edycji fototypicznej: Mikołaj Rej, Postylla, cz. II (wydanie fototypiczne), Wrocław-Warszawa-Kraków, MCMLXV („Biblioteka Pisarzów Polskich”, seria B, nr 14); transkrybuję zasadniczo w oparciu o instrukcję dla wydań typu A (por. Zasady wydawania tekstów staropolskich. Projekt, oprac. K. Górski i in., red. M. R. Mayenowa, przykłady oprac. J. Woronczak, Wrocław 1955), zmodyfikowaną jak w edycji: Mikołaj Rej, Apocalypsis, red. W. Kriegseisen, oprac. M. M. Kacprzak, S. Kawczyński, J. T. Maciuszko, I. Winiarska, Warszawa 2005. 
wyróżnianych sensów Pisma zainteresuje kaznodzieję głównie moralny; zarazem weryfikuje się tu znacząco zapowiedź z tytułu: nauka związana z Maryją jako wzorem dotyczy wprawdzie kobiet, odnosi się jednak do każdego, niezależnie od płci i stanu, w jego doświadczeniu szczęścia. Rej przypomina wydarzenia poprzedzające Nawiedzenie — fakty z Ewangelii św. Łukasza sprzed wyprawy Maryi, a także całą historię ludzkości od rajskich początków: grzech pierworodny jako przyczynę oddzielenia od Boga; daną Prorokom i Patriarchom obietnicę zbawienia przez wcielonego Boga; łaskawą i wolną decyzję Boga o spełnieniu obietnicy; odwieczny wybór panny na matkę Boga-Człowieka i proroctwo o dziewiczym poczęciu z Ducha; Zwiastowanie Maryi; poczęcie św. Jana Chrzciciela posłanego przed Mesjaszem (Łk 1, 1-38; Rdz 3; Iz 7, 14 i Mt 1, 23; Iz 40, 3 i Mt 3, 3; Mk 1, 3; Łk 3, 4; J 1, 23). To streszczenie historii upadku i zbawienia akcentuje w typowej perspektywie protestanckiej grzech pierworodny, wolną wolę i miłosierdzie Boga oraz pewność Jego obietnic. Ta „prehistoria” Nawiedzenia zawiera sformułowania, które podkreślają unię natury Boskiej i ludzkiej w Chrystusie oraz pochodzenie od Maryi Jego natury ludzkiej, Jej Boże macierzyństwo, a także odwieczność wyboru na Matkę Bożą. Nie może to dziwić w świetle ewangelickich wypowiedzi doktrynalnych (począwszy od $M a-$ tego i Dużego Katechizmu Marcina Lutra oraz Konfesji Augsburskiej, przez Katechizm Genewski, po Wyznanie szwajcarskie późniejsze) $)^{6}$, z których jasno wynika, że zgodnie ze świadectwem Biblii i orzeczeniem Soboru Efeskiego z 431 roku Maryja jest Theotokos, Matką Boga, co nadaje Jej najwspanialszą godność (poza unią hipostatyczną w Jezusie), jaką zostało obdarzone stworzenie; sam Luter eksponował prawdę o Maryi jako matce całej Osoby Boga-Człowieka ${ }^{7}$. Z uwagą zatrzymuje się też Rej

${ }^{6}$ Por. np. w: Teksty o Matce Bożej. Chrześcijaństwo ewangelickie, wstęp, wybór i oprac. S. C. Napiórkowski, przeł. E. Adamiak, M. Daniluk, K. Kowalik, S. C. Napiórkowski, M. Straszewicz, H. Ulrich, Niepokalanów 2000.

7 Por. S. C. Napiórkowski, Pomost czy przepaść?, w: Id., Spór o Matkę..., s. 118 122; Id., Maryja w teologii i pobożności ewangelików, w: Teksty o Matce Bożej..., s. 19; J. Gross, op. cit., s. 102-103; K. Kowalik, Matka Pana w teologii i pobożności chrześcijańskiej wedtug Komentarza do Magnificat Marcina Lutra, w: Teksty o Matce Bożej..., s. 64-71; Id., Matka Pana $w$ Komentarzu do Magnificat Marcina Lutra (1521), w: Matka Boża w ludzie Bożym, red. J. Górecki, Katowice 2005, s. 84-86, 204-205; W. Nowak, Maryja przygotowana przez Ducha Świętego, wybrana przez Boga Ojca na Matkę Jego Syna w religijności ewangelików, w: Trójca Święta a Maryja. Materiaty z sympozjum mariologicznego zorganizowanego przez Polskie Towarzystwo Mariologiczne. 
na dogmacie o dziewiczości poczęcia Chrystusa z Ducha Świętego, przy czym podkreśla jego transcendentność wobec ludzkiej rzeczywistości. Znamienne, że jeśli chodzi o dziewiczość Maryi, explicite wypowiada się o poczęciu, nie odnosi się natomiast bezpośrednio do wiary w wieczne dziewictwo, zachowane podczas porodu (in partu) i po nim (post partum $)^{8}$. To typowe dla pisarzy ewangelickich — wiarę, że Jezus począł się z Ducha bez udziału mężczyzny, wyrażają często jako opartą na Biblii, a problem wiecznego dziewictwa nie interesuje ich, skoro Biblia do tej wiary nie zobowiązuje, a nie ma to dla teologii i wiary doniosłego znaczenia? ${ }^{9}$ Jednak stałe operowanie określeniem „panna” w kazaniu Reja nie tłumaczy się tym, że dotyczy ono wydarzeń sprzed narodzenia, raczej zaświadcza przekonanie, że to stała cecha Marii (nazwy „Dziewica” używał i Luter jak imienia własnego, pojmując dziewictwo Marii jako wieczne i skupiając się na niezwykłości działania Boga ${ }^{10}$. Ostatnie wprowadzenie do perykopy wskazuje na jej najważniejsze elementy: słowa Elżbiety o Maryi, która uwierzyła obietnicom (Łk 1, 42-45), i fragment hymnicznej odpowiedzi Maryi, owego drugiego wersetu Magnificat (Łk 1, 47). Słowa Maryi przedstawia kaznodzieja m.in. jako przejaw Jej wielkiej radości i zaleca zachowanie ich w pamięci jako wzór właściwej reakcji na szczęście: postrzeganie Boga jako jedynego źródła szczęścia i jedynej nadziei. Interesujące, że dialog Elżbiety z Maryją został także wprowadzony słowami bez źródła w Ewangelii, gdzie czytamy o pozdrowieniu Elżbiety przez Maryję, ruchu Jana na głos Marii i natchnionym przez Ducha błogosławieństwie Maryi przez Elżbietę (Łk 1, 40-42), a brak Rejowej informacji o wstępnej rozmowie niewiast na temat anielskich zwiastowań; wiedza Elżbiety o Zwiastowaniu Maryi ma więc charakter proroctwa. Apokryficzny i racjonalizujący dodatek Reja o tym, że kobiety opowiedziały sobie o objawieniach, niejako zdejmuje

Częstochowa, 6-8 września 1999 roku, red. nauk. T. Siudy, K. Pek MIC, Częstochowa 2000, s. 227-240.

8 Por. Maria, Matka Boga, zawsze Dziewica, w: H. Bourgeois, B. Sesboüé, P. Tihon, Znaki zbawienia. Sakramenty - Kościót - Najświętsza Panna Maria, tłum. P. Rak, red. nauk. T. Dzidek, Kraków 2001 („Historia dogmatów”, t. III), s. 496-502.

$9 \quad$ Por. S. C. Napiórkowski, Pomost czy przepaść?..., s. 118-122; Id., Maryja w teologii i pobożności ewangelików..., s. 19; J. Gross, op. cit., s. 102-103, 204-205; W. Nowak, op. cit., s. 227-240.

10 Zob. K. Kowalik, Matka Pana $w$ teologii..., s. 64-71; Id., Matka Pana $w$ Komentarzu..., s. 84-86. 
z nich część ciężaru wiedzy nadprzyrodzonej i prorockiego natchnienia; czyni je bardziej zwykłymi, gdy w chwili spotkania dużo mówią o wydarzeniach w życiu ich rodzin.

Po perykopie ${ }^{11}$ Rej zaczyna właściwe kazanie od ważkiego zastrzeżenia, które uprzedza ewentualne zarzuty: deklaruje, że nie ma na celu odbierania czci Maryi ani uwłaczania Jej godności. Oddawanie każdemu tego, co mu należne, to zresztą imperatyw uniwersalny i uzasadniony skrypturalnie (w adresach na marginaliach: „Matteusz w XII. Marek w XXII.” pisarz lub drukarz popełnia błąd, zamieniając numery rozdziałów przy imionach Ewangelistów; chodzi z pewnością o teksty $\mathrm{Mt}$ 22, 15-22 i Mk 12, 13-17 o oddaniu Boskiego Bogu, a cesarskiego cezarowi; parafrazuje się tu także $\mathrm{Rz} 13,7)$. Uznanie cnoty i godności Marii okazuje się na mocy Pisma niezbędne, także ze względu na stosunek do Niej Boga Trójjedynego, który Ją odwiecznie wybrał, szczególnie obdarował i zapowiedział w proroctwie o różdżce z pnia Jessego (Iz 11, interpretowany chrystologicznie i mariologicznie), w pozdrowieniu Anioła (Łk 1, 28) i Elżbiety (Łk 1, 41-45; tym razem Rej eksponuje natchnienie Elżbiety). Na początku nauki kaznodzieja przypisuje więc Maryi wyjątkową godność, podkreślając jej źródło w Bożej woli uczynienia Jej matką Chrystusa i napełnienia łaską. Podąża tą samą drogą, co choćby Luter, dla którego Boże macierzyństwo jest rekapitulacją wszystkich darów i łask Maryi — „wielkie rzeczy” z Magnificat to właśnie Boże macierzyństwo, a wszystkie inne przymioty nie usposabiają Maryi ani nie zasługują, ale są wpisanym w dar Bożego macierzyństwa „wyposażeniem”, udzielonym darmo. Zgodnie z Komentarzem do Magnificat Lutra z 1521 roku tytuł Matki Boga jest najwznioślejszym ${ }^{12}$.

Znamiennie traktuje też Rej słowa Anioła o pełnej łaski (Łk 1, 28), używane w dogmatyce katolickiej jako argument za niepokalanym poczęciem Marii - oczywiście brak tu aluzji do takich treści, a interpretacja wydobywa temat stałej obecności Boga przy Maryi i obdarowanie łaską. To zignorowanie tematu jest charakterystyczne dla ewangelicyzmu, dla którego niepokalane poczęcie (w tym czasie bez rangi dogma-

11 Por. K. Górski, Biblia $i$ sprawy biblijne $w$ Postylli Reja, w: Id., $Z$ historii $i$ teorii literatury, Wrocław 1959, s. 7-50; Id., Pochodzenie tekstu, s. 8-9; A. Brückner, op. cit.; J. Kolbuszewski, op. cit.; J. T. Maciuszko, op. cit., s. 297-302; M. M. Kacprzak, „Mariologia”....

12 Zob. K. Kowalik, Matka Pana $w$ teologii..., s. 64-71; Id., Matka Pana $w$ Komentarzu..., s. 84-86. 
tu, jednak od rozstrzygnięcia Dunsa Szkota przyjęte dość powszechnie w katolickiej mariologii i pobożności) nie znajduje podstaw w Biblii, co zważywszy na postulat sola Scriptura, stanowi argument rozstrzygający $^{13}$. Tymczasem słowa Elżbiety o wierze Marii zinterpretował Rej w duchu protestanckiej wizji wiary jako fundamentu życia duchowego: błogosławieństwo Maryi to znak Jej niezmiennej wiary — zaufania pokładanego w Bogu.

Po wyeksponowaniu godności Matki Bożej i zaleceniu Jej właściwej czci następuje refleksja nad tej czci naturą. Gwarancja jej poprawności to nieograniczanie czci i chwały należnej Bogu. Z Jego bowiem woli, ze względu na fundamentalną różnicę ontologiczną między Nim i stworzeniem, człowiek nie może dopuszczać się bałwochwalstwa, oddając cześć Boską komukolwiek i czemukolwiek poza Nim (tu argumentacja fragmentami Starego Testamentu o jedyności Boga i zakazie kultu bożków: Wj 20, 1-5, 22-26 i Iz 43, 10-15). Kościelne wspomnienia wydarzeń z życia Matki Bożej mają więc polegać na medytowaniu nad cudami Bożymi w Niej i przypisywaniu całej chwały Bogu. Mają też służyć czerpaniu z Niej zbawiennego przykładu; w dzień Nawiedzenia przykład ten dotyczy głównie oddawania chwały Bogu, przypisywania Jemu, a nie sobie wszelkiej zasługi. Podobnie w Komentarzu do Magnificat Luter powiązał traktowanie Maryi jako wzoru z refleksją nad sposobem oddawania Jej czci - jego uprawniona forma to wysławianie objawionej w Niej łaski Bożej; szacunek, którego Maria jest godna, ma się wyrażać w podziwianiu w Niej darów Boga i uwielbianiu Go, przy uznaniu Marii za przykład Bożej łaski i wzór do naśladowania w zakresie chwalenia Boga, pokory i wiary ${ }^{14}$. To ujęcie wiąże się także z ważką zasadą soli Deo gloria - czwartym „tylko" Kościoła reformowanego ${ }^{15}$. Dla Reja czcią należną Maryi jest stwierdzenie za Elżbietą, że Jej błogosławieństwo płynie z wiary, wiążącej się z wyborem na matkę Boga-Człowieka. Kaznodzieja podkreśla, że ta interpretacja roli Maryi

13 Zob. S. C. Napiórkowski, Pomost czy przepaść?, s. 118; W. Nowak, op. cit., s. 230231, 233.

14 Por. S. C. Napiórkowski, Pomost czy przepaść?, s. 118, 122; por. Marcin Luter, Komentarz do Magnificat (1521), tłum. K. Kowalik, w: Teksty o Matce Bożej..., s. 134.

15 Por. S. Piwko, Jan Kalwin. Życie i dzieto, Warszawa 1995, s. 60, 72; M. M. Kacprzak, „Niech kamienie wota... ” Mikotaj Rej o roli literatury, pisarza i wtasnej twórczości, w: Mikotaj Rej w pięćsetlecie urodzin. Studia literaturoznawcze, red. J. Sokolski, M. Cieński, A. Kochan, Wrocław 2007, s. 100. 
zgadza się z wolą Jej samej, wyrażoną w Magnificat w sprzeciwie wobec bałwochwalstwa (także Luter, komentując Magnificat, ukazywał katolicki kult jako niemiły Maryi, która nie chce być bożkiem) ${ }^{16}$. Maryję należy bowiem czcić tylko ze względu na Syna, macierzyństwo, które uczyniło z Niej święty przybytek Boga (to szczególne odniesienie do Maryi nauki św. Pawła o chrześcijaninie jako świątyni Boga żywego, mieszkaniu Ducha Świętego: 1 Kor 3, 16-17; 6, 19; 2 Kor 6, 16). Taką cześć zestawia Rej kontrastowo ze „staroświeckim”, czyli tradycyjnym Jej kultem, zarzucając katolikom zniekształcenie wspomnień maryjnych i traktowania Matki Bożej w modlitwie. Uderza szczególnie w wiarę we wniebowzięcie Maryi i jego świętowanie; czyni to w najmocniejszy dla protestanta sposób, zarzucając brak potwierdzenia w Biblii oraz wytaczając przeciw niemu argument z ewangelicznych słów Jezusa do Nikodema o jedyności wniebowstąpienia Syna Człowieczego (J 3, 13; Ef 4, 10). Postawa Reja wobec wniebowzięcia (także wówczas bez rangi dogmatu) jest zupełnie typowa dla teologii protestanckiej, odrzucającej je jako niepotwierdzone w Piśmie i starożytnej tradycji Kościoła ${ }^{17}$. Katolicki kult wniebowzięcia jest dla Reja zdrożny jako odbieranie chwały Bogu, a pokładanie nadziei w Maryi, czynienie z Niej, jak odczytuje kaznodzieja z modlitw i pieśni maryjnych, pośredniczki, orędowniczki i rozdawczyni łask, podczas gdy wyznanie wiary w Symbolu Apostolskim i Nicejsko-Konstantynopolitańskim ukazuje w chwale niebieskiej królującego Zbawiciela, a Biblia mówi o wyłącznym pośrednictwie Chrystusa $(\mathrm{J} 3,16)$. Teologowie ewangeliccy rzymskokatolicki kult Marii (zwłaszcza w formie popularnej) wraz z ideą Jej pośrednictwa uznają za niewłaściwy, twierdząc właśnie, że nie ma podstaw w Piśmie i tradycji, stoi w sprzeczności z biblijnym świadectwem o jedynym Pośredniku i zagraża czci Chrystusa (nie dotyczy to zresztą tylko Marii, ale wszystkich świętych; odrzucenie ich pośrednictwa przedstawia się modelowo w Apologii Konfesji Augsburskiej, a powraca z mocą np. w Katechizmie Genewskim czy w Komentarzu do Nowego Testamentu Jana Kalwina) ${ }^{18}$.

16 Por. Marcin Luter, Komentarz do Magnificat, s. 134-135.

17 Zob. S. C. Napiórkowski, Pomost czy przepaść?, s. 118; J. Gross, op. cit., s. 106, 208.

18 Por. S. C. Napiórkowski, Maryja w teologii i pobożności ewangelików, s. 19-28; Id., Pomost czy przepaśc??, s. 118; Id., Maryja ewangelików, w: Id., Matka Pana (problemy - poszukiwania - perspektywy), Niepokalanów 1998, s. 129-136; J. Gross, op. cit., s. 107-109, 209-211; Wprowadzenie do: Jan Kalwin, [Maria i cud wina w Kanie, 
Rej więc z siłą i zjadliwością, z temperamentem satyryka krytykuje obrzędy związane z katolicką liturgią świąt maryjnych. Odrzuca jako wymysły, odległe od prawdziwej pobożności biblijnej, obyczaj święcenia ziół w uroczystość Wniebowzięcia i obrzęd święcenia świec w święto Oczyszczenia Najświętszej Marii Panny i następujący po nim dzień św. Błażeja. Zarzuca katolickiej obrzędowości bałwochwalczą cześć wobec przedmiotów i stworzeń, pokładanie nadziei w nich zamiast w opiece Boga (tu argument biblijny: Ps 91 (90)). Te praktyki liturgiczne chce skompromitować, uznając za ich źródło błędną i trywialną interpretację przekazu biblijnego - fragment liturgii święcenia świec, oparty na słowach Symeona o świetle na oświecenie pogan (Łk 2, 32), przedstawia jako oddanie zwykłemu przedmiotowi tego, co przynależne prawdziwej Światłości - Bogu. Katolickie obrzędy święcenia przedmiotów, które, według Reja, nie zmieniają ich natury ani właściwości, zostały ukazane jako magiczne, oparte na czarach, a więc bluźniercze, ale też zwyczajnie śmieszne. By świętować w sposób godny chrześcijanina, a nie pogański, miły Jezusowi i Jego Matce, a nie ubliżający Jej godności, należy zastąpić te praktyki medytacją o Zbawicielu.

Kaznodzieja patrzy na ewangeliczne Nawiedzenie jako na spełnienie Bożej obietnicy wybrania tego, co małe w oczach świata, i zawstydzenia ludzkiej mądrości — odwołuje się do koncepcji św. Pawła, związanej ze słynną tezą o głupocie Krzyża (1 Kor 1, 27-29) i tekstami starotestamentowymi o Bożej Mądrości, przede wszystkim z Księgi Izajasza (Iz 29, 14; 19, 12). Analizuje więc perykopę jako objawienie odmienności mądrości i działania Boga i człowieka. Obyczaje wielkich tego świata związane z poczęciem potomka (rozsyłanie gońców z wieściami i darami) zestawia kontrastowo z opisem ewangelicznym. Choć nieustannie przypomina o szczególnej godności Maryi — matki Boga-Człowieka, równocześnie podkreśla Jej niski stan oraz odpowiadającą mu pokorę (podobnie wskazuje na niski stan i pobożną prostotę Elżbiety w odwołaniu do Łk 1, 6). Przeciwstawia Maryję mocarzom i mówi wprost o bohaterkach: „to maluczkie dwie osobce były, jedna pokorniuchna dzieweczka, a druga prosta a święta babeczka [...] to barzo małe dwie osobie były"; z tą tendencją można wiązać przedstawienie Marii i Elżbiety jako zwykłych gadatliwych kobiet na początku kazania. Podkre-

fragment rozdziału II Komentarza do Nowego Testamentu], [Maria pod krzyżem], tłum. S. C. Napiórkowski, w: Teksty o Matce Bożej..., s. 157. 
ślenie niskiego stanu Marii i jej krewnej wydobywa transcendencję Bożych dzieł wobec zasad świata w duchu 1 Listu do Koryntian i Księgi Izajasza, a współbrzmi ze słowami o wielkich dziełach Boga (Łk 1, 49) oraz o ukorzeniu mocarzy i wywyższeniu pokornych (Łk 1, 51-52). Odczytanie sensu Nawiedzenia opiera się na dostrzeżeniu dysproporcji między niskim stanem Maryi i Elżbiety a wielkością Bożych dzieł z ich udziałem („Z małych dwu osob wielkie sie rzeczy zjawiły”). Z woli Boga prostym niewiastom przydarzyło się to, co nie spotkało najmożniejszych. Jako wyjątkowy przykład Bożych dzieł nad maluczkimi przedstawiono narodziny Jezusa $\mathrm{z}$ towarzyszącymi im cudownymi znakami (Łk 2, 13-14). Boże Narodzenie spełnia Bożą obietnicę, proroctwo Maryjnego Magnificat. Pokój przychodzący na ziemię z narodzinami Jezusa i zwiastowany pasterzom to zapowiedziane przez Maryję zwycięstwo nad mocarzami (Łk 1, 51-52), których interpretuje kaznodzieja na płaszczyźnie metafizycznej jako szatana, śmierć wieczną i grzech; te trzy wrogie potęgi przedstawia Rej na tle biblijnych wypowiedzi o ich upadku (o szatanie — Łk 11,21-22, o śmierci — Oz 13, 14, o grzechu - $1 \mathrm{~J}, 1,1)$. Proroctwo Magnificat o mocarzach i pokornych ma realizować także sam Jezus przez stosunek do faryzeuszy, uczonych w Piśmie i ludzi o wysokiej pozycji społecznej, pysznie ufających swej wierności Prawu, z drugiej zaś strony — do rybaków i innych prostaków oraz doświadczanych (Mt 11, 25 i 11, 5). Przejawem upokorzenia możnych ma być np. lęk Heroda i jego popleczników na wieść o narodzinach Mesjasza (Mt 2). Kaznodzieja, zgodnie z własnym zaleceniem, wykorzystuje więc wydarzenia związane z osobą Maryi dla rozpatrywania dzieł Boga, mocy i łaski Chrystusa. Największe dzieło tej łaski to zbawienie, dokonane z woli Boga przy udziale Maryi. Rejowe ukierunkowanie interpretacji perykopy na uniżenie wielkości świata i wywyższenie małego oraz na Boży sąd odmienny od ludzkiego, a także na niski stan Maryi domaga się interpretacji na tle Lutrowego Komentarza do Magnificat, w którym pieśń tę odczytuje się m.in. jako wyraz zachwytu nad wyniesieniem mocą Bożej łaski tego, co poniżone. Według Reformatora, Magnificat ukazuje w Maryi człowieka przyjętego do łaski mimo braku zasług i wbrew ludzkiemu zrozumieniu. Radykalnie rozróżniając między Boskim a ludzkim, ukazuje Luter działanie Stwórcy, który z niczego tworzy wielkość Matki Chrystusa, czyni wielkim to, co słabe i poniżone. Obraz Maryi buduje więc Luter z paradoksów - wyniesiona 
przez Boga ponad ludzkość, pozostaje nic nieznaczącą; z upodobaniem podkreśla Reformator Jej marność w oczach świata, eksponuje Jej niski stan społeczny (także proroctwo o różdżce Jessego interpretuje m.in. w odniesieniu do historii upadku i wywyższenia rodu Dawida) ${ }^{19}$.

Część kazania poświęcił Rej, zgodnie z zapowiedzią, Maryi jako wzorowi osobowemu dla kobiet wszystkich stanów, wskazując adekwatne fragmenty perykopy (Łk 1, 39; 56) oraz zachowania Matki Boskiej. Najpierw zatrzymuje się na temacie pośpiechu w drodze do Elżbiety. Rozwija komentarz w typowy dla swego pisarstwa, pełen detali obrazek rodzajowy ${ }^{20}$, ukazując, niemal satyrycznie, charakterystyczne dla kobiet zachowania negatywne, których uniknęła Maryja — marnowanie czasu i pieniędzy na stroje i środki upiększające, kokieterię i sztukę uwodzenia, nadmierne poświęcanie uwagi prezencji:

[...] sie nic nie bawiła, biegając po kramikoch, kupując źwierciadłka, tkaneczki, brameczki, bryżyczki, barwiczki i ine rzeczy świata tego, nic sie nie obzirając, a nie strojąc postawek to tam, to sam, na każdą stronę nic nie patrząc, aby ukazowała trzewiczek, a iżby nie zmyliła kroku swego, nic sie nie skubąc po głowie, poprawując forbotkow, bryżykow abo wianeczkow, ale szła s kwapieniem a s pilnym rozmyślaniem w sercu swoim o łasce a o miłosierdziu Pana swojego.

W Maryi krytykowane zachowania zastąpił pośpiech oraz gorliwe skupienie medytacyjne na Bożej łasce; dlatego Maria jest dla kobiet wzorem do naśladowania, bez którego stać się one mogą jedynie obiektami gapiowskiego zadziwienia. Aby poruszyć sumienia, nie cofa się kaznodzieja przed wzbudzeniem strachu przed gniewem Boga. Litując się nad niewiastami zajętymi pozorami tego świata, ukazuje je jako „niebożątka”, które nie rozpoznają swojej rzeczywistej sytuacji, groźnej, bo wzbudzającej gniew uważnie śledzącego je Boga; sytuacja ta nosi znamiona losów pysznego grzesznika ze Starego Testamentu, psalmicznego głupca, który chce kierować życiem bez Boga, nie zdając sobie sprawy z nadciągającej kary, objawianej przez Boży śmiech (Ps 10, 11; 73, 11; 94,7;

19 Por. K. Kowalik, Wprowadzenie do: Marcin Luter, Komentarz do Magnificat, s. 129-130; Id., Matka Pana $w$ teologii..., s. 83-84; Id., Matka Pana w Komentarzu..., s. 92-95.

20 Por. E. Ostrowska, Bruegel polskiej literatury, w: Ead., Z dziejów języka polskiego i jego piękna, Kraków 1978 lub w: Mikotaj Rej. W czterechsetlecie śmierci, red. T. Bieńkowski, J. Pelc, K. Pisarkowa, Wrocław 1971, s. 192. 
Syr 16, 17-23) 21 . Boża pomsta nad dumnymi grzesznicami (niewiastami syjońskimi interpretowanymi alegorycznie jako chrześcijanki) ${ }^{22}$ i ich mężczyznami, jako zapowiedziana w Księdze Izajasza (Iz 3, 16-26) jest dla kaznodziei nieodwołalna bez poprawy obyczajów. Wspomniany obrazek rodzajowy pojawia się więc w kazaniu nie tylko przez „malarski” i satyryczny temperament Reja, ale i w relacji do parafrazowanego tu, podobnego stylistycznie obrazu biblijnego:

[...] ony chodzą z wyciagnionemi szyjami a s podniosłemi głowami, krocząc, a rozlicznie stawiając nogi swoje, mrugając, a na stronę obracając oczy swoje, a w pysze podnosząc głowy swoje. [...] ja przeto każę odrzeć a obłysić tu marne głowy ich, a poszpecę i każę odebrać od nich ty wymyślne ubiory ich, ty perły, ty pstre bramki, ty bryżyki, ty zaponki, ty źwierciadłka, ty rozliczne wonności ich.

Czyni to krytykę pysznych kobiet jeszcze bardziej zjadliwą i mocną ideowo, skoro utożsamia je z grzesznymi i zagrożonymi Bożą pomstą córami Syjonu. Przykład Maryi okazuje się zaś zbawienny, skoro pozwala pomsty uniknąć. Kaznodzieja troszczy się przy tym, by nikt nie uważał, że wezwanie do przemiany go nie dotyczy — zgodnie z Biblią podkreśla, że groźba dotyczy też mężczyzn. Warto zwrócić uwagę, iż krytyka nie obejmuje tu urody i majątku wykorzystywanych z umiarem. Rej ceni wartości doczesne otrzymane od Boga i nie chce być źle zrozumiany w duchu ich negacji — dookreśla, że problemem jest niewłaściwy stosunek do dobrodziejstw: brak umiaru w korzystaniu z nich oraz pycha przypisywania zasługi sobie i zapominania o Bogu-Dawcy. Maryja to wzór do naśladowania właśnie w postawie wobec darów, za które chwali Boga. Tak jest też ukazywana w Lutrowym Komentarzu do Magnificat, jego pierwszym wykładzie Psalmów czy wykładzie Listu do Rzymian ${ }^{23}$.

${ }_{21}$ Por. Bezbożnik, w: Stownik teologii biblijnej, red. nacz. X. Leon-Dufour, tłum. i oprac. K. Romaniuk, Poznań 1994, s. 67-69; A. Tronina, Teologia Psalmów. Wprowadzenie do lektury Psatterza, Lublin 1996, s. 67, 92; Gtupota, w: Stownik teologii biblijnej, s. 286; S. Witek, Gtupota, w: Encyklopedia katolicka, red. L. Bieńkowski i in., t. 5, Lublin 1989, szp. 1155; M. M. Kacprzak, Myśl o Bogu i cztowieku w „Żywocie Józefa..." Mikotaja Reja, Warszawa 2003, s. 171-172.

22 Por. J. T. Maciuszko, op. cit., s. 401.

23 Por. K. Kowalik, Wprowadzenie do: Marcin Luter..., s. 129; Id., Matka Pana $w$ Komentarzu...., s. 81, 89, 94-95; Id., Matka Pana $w$ teologii..., s. 60, 83-84. 
Kaznodzieję zaprząta też obraz Maryi usługującej kuzynce. Przedstawia Ją jako przykład pokornego podporządkowania się kobiety tym, którzy mają nad nią władzę. Operuje tu argumentacją pozytywną, kształtując obraz niewiasty wzorowej, troszczącej się o dom i stale w nim obecnej, poza nim zaś dbającej o zachowanie godności i cnoty. Jak krytyczno-satyryczny obraz niewiasty pysznej miał pierwowzór biblijny, tak i ten zakorzeniony jest w Piśmie świętym — na marginesie czytamy: „Jako Pan wysławia stan poczciwej białej głowy” i rzeczywiście napotykamy tu przywołanie biblijnej pochwały dzielnej niewiasty (Prz 12, 4; 31, 10-31), zabiegającej gospodarnie o dom i rodzinę, pobożnej, godnej uznania. Konkretyzując, kaznodzieja zaleca adresatce, aby na wzór Maryi pozostawała w zależności od stanu posłuszna rodzicom lub mężowi, a także pokornie nieufna wobec swego rozumu. Znamienne, że argumentacja dla drugiego z zaleceń nie odnosi się tylko do kobiety, ale dotyczy natury człowieka, prezentowanej, zgodnie z antropologia protestancka, jako bezpowrotnie skażona grzechem, skłonna do upadku i nieprzezwyciężalna na drodze rozumowej ${ }^{24}$. Świadomość własnej marności to właśnie pokora, która odgrywa główną rolę w obrazie Maryi również w Komentarzu do Magnificat Lutra (Marię - uosobienie pokory przedstawiał on także np. w kazaniu na święto Nawiedzenia z 1523 roku, eksponując usługiwanie przez Nią innym) ${ }^{25}$. Dla Reformatora pokora to nie cnota zasługująca, ale (w utożsamieniu z wiara) — wskazanie na bezsilność człowieka ${ }^{26}$. Polski kaznodzieja u kresu wywodu poświęca więcej uwagi tej cesze Maryi, tak rzadkiej we współczesnym świecie, i znów ze zmysłem malarza obyczajów przedstawia typowe zachowania, ironicznie obnażając bezpodstawność ludzkich roszczeń wobec przyszłej godności potomków. Nie zatrzymuje się jednak na prześmiewczej krytyce, ale zwraca się ku pozytywnemu wykładowi o zachowaniu w doświadczeniu szczęścia. Opiera go nie tylko na przykładzie Maryi, ale i innych bohaterek biblijnych - Anny, matki Samuela, która obdarowana synem po latach niepłodności, wyśpiewała kantyk porównywany z Magnificat (1 Sm 1-2, 11); Elżbiety, skromnie ukrywającej przed ludźmi cud poczęcia (notabene Rej popełnia błąd, mówiąc o trzech miesiącach zachowania tajemnicy, a nie, jak czytamy w

24 Por. J. T. Maciuszko, op. cit., s. 401.

25 Por. ibidem, s. 207.

26 Por. K. Kowalik, Matka Pana $w$ Komentarzu..., s. 97-99; Id., Matka Pana w teologii..., s. 86-89. 
Łk 1, 24-25, o pięciu); siostry Aarona Miriam, która po przejściu przez Morze Czerwone podjęła pieśń i powiodła taneczny korowód kobiet ku chwale Boga (Wj 15, 20-21); Zuzanny (Dn 13; to zapewne drukarz podał na marginaliach zły adres: „I. Do korin. w XIII.” zamiast: „Daniel w XIII.”). O wyborze tych postaci jako przykładów do naśladowania stanowi postawa pokory $\mathrm{w}$ doświadczeniu szczęścia, nieprzypisywanie sobie zasługi, a oddawanie, przede wszystkim w duchu, chwały Bogu jako sprawcy radości. I tu Rej porzuca perspektywę „kobiecą” na rzecz uniwersalnej: w zwrocie do chrześcijanina dowolnego stanu zaleca postępowanie w szczęściu na wzór Maryi i biblijnych niewiast, czyli wyznanie radości jako dzieła Boga. Kaznodzieja proponuje modlitwę parafrazą drugiego wersetu Magnificat, przywołanego na początku jako swoiste motto i powracającego w kazaniu. Takie naśladowanie Matki Bożej ma owocować Bożym błogosławieństwem.

Podsumowanie kazania precyzuje jego dwa zasadnicze przesłania. Pierwsze dotyczy właściwej czci Matki Bożej i świętych — odnosi się do protestancko-katolickiej polemiki wokół zasadności i formy kultu świętych, ze szczególnym uwzględnieniem Maryi. Rej potwierdza, że właściwe obchodzenie kościelnego wspomnienia Nawiedzenia i chwalenie Matki Bożej to: rozmyślanie nad Jej doświadczeniami i czynami, poprawianie swego życia przez naśladowanie Jej przykładu, oddawanie Bogu jako sprawcy wszelkiego dobra chwały i dziękczynienia za Jej osobę. Ma to być pozytywne przeciwieństwo tradycji katolickiej, sprowadzanej do bezmyślnej pobożności i obrzędowości o cechach magicznych (świece przed obrazami, ozdabianie figur i obrazów kwiatami i sukienkami, święcenie ziól), a przedstawianej satyrycznie z ironią. Drugie przesłanie kazania, dla wszystkich chrześcijan, ale szczególnie dla kobiet, to zalecenie naśladowania przykładu Matki Bożej w zakresie nieprzypisywania sobie żadnej zasługi i chwały oraz dziękczynnego chwalenia Boga, z którego woli pochodzi wszystko, także szczęście. Ostatni raz pojawia się tu parafraza, centralnego w kompozycji kazania, fragmentu Magnificat o radości w Bogu (Łk 1, 47). Fakt, że kaznodzieja kończy tekst modlitwą, to realizacja jego własnej nauki, by chwalić Boga jako źródło wszelkiego dobra. Treść modlitwy, zanoszonej przez „nędzników” — słabe istoty o niskiej kondycji — do Boga - władcy mogącego spełnić każdą prośbę, a połączonego z człowiekiem więzami miłości — to prośba o pomoc w naśladowaniu 
Matki Bożej. Ma ono dotyczyć stałej wiary i pokory, którą Maryja uzyskała i pomnożyła dzięki Bożemu natchnieniu. Postawa ta winna się łączyć ze stałością serca i umysłu, która przywodzi na myśl zalecenia stoickie, bo oznacza brak zasmucenia w dopuszczanych przez Boga doświadczeniach i niezdrowego unoszenia się w szczęściu, a także jednakowe dziękczynienie za wszystko (pobrzmiewa tu echo listów apostolskich - 1 Tes 5, 18 czy Ef 5, 18-20). Notabene, choć jak w całym kazaniu, tak w podsumowaniu i końcowej modlitwie Maryja nazywana jest świętą i „chwalebną” (tzn. otoczoną chwałą, godną chwały), choć z uznaniem i atencją docenia się Jej godność, podkreślając Jej odwieczne wybranie przez Boga, dziewictwo i macierzyństwo Boże — nie kieruje się do Niej żadnej prośby.

Jakub Wujek

We wprowadzeniu do homilii Wujek przedstawia sens parenetyczny perykopy — dwie postaci kobiece, ich czyny, mowy i postawy to wzór do naśladowania, głównie dla kobiet. Marię i Elżbietę charakteryzuje przez paralelę i kontrast: to święte, brzemienne matki, które cudownie poczęły, dziewica i niepłodna a niemłoda mężatka, matki Pana i sługi, Mesjasza i Eliasza (czyli proroka), Boga i Anioła (czyli Boskiego posłańca). Wskazuje więc na wysoką godność obydwu bohaterek, ale i nieporównywalną wyższość Matki Bożej.

Interpretację rozpoczyna od pytania o przyczynę wydarzenia. Przywołuje scenę Zwiastowania dla fabularnego uzasadnienia Nawiedzenia — od Anioła Maria dowiedziała się o stanie Elżbiety. To jednak tylko punkt wyjścia do podkreślenia czystych intencji Maryi: nieprawda, że nie uwierzyła Aniołowi czy, wątpiąc, chciała sprawdzić rzetelność jego słów, nieprawda, że dumna zamierzała się pochwalić łaską. Kierowały Nią (relacjonuje Wujek za św. Ambrożym, jego Wyktadem Ewangelii wedtug św. Łukasza ${ }^{27}$ : radość z cudownych poczęć, pragnienie uradowania przyjaciółki, usłużenia jej i wspólnego radowania się w Bogu oraz natchnienie Ducha Świętego, który przez obecność Maryi napełnił nienarodzonego Jana i ziścił obietnicę daną Zachariaszowi.

27 Por. Św. Ambroży, Wyktad Ewangelii wedtug św. Eukasza, tłum. W. Szołdrski, oprac. i wstęp A. Bogucki, Warszawa 1977 („Pisma starochrześcijańskich pisarzy”, t. 16). 
Uwagę kaznodziei zatrzymuje tradycyjnie pośpiech Maryi. To, że okazała się „prędka ku dobremu”28, tłumaczy (wciąż za Ambrożym) wykładem o miłości Bożej, której znamię to aktywne czynienie wielkich rzeczy. Refleksja mariologiczna przechodzi w moralistyczną: wezwanie do miłości na wzór Maryi łączy się z alegorycznym zastosowaniem Jej wędrówki do życia duchowego - należy bez ociągania powstać ze snu grzechów ( $\mathrm{Rz} 13,11-14)$, z pośpiechem nawrócić się i ruszyć z ziemskich nizin ku górom nadprzyrodzoności (Kol 1, Flp 3), w świadomości, że od krótkiej i niepewnej doczesności zależy wieczność (Koh 5, Koh 9, Mdr 2). Kaznodzieja wymienia czyny, które objawią miłość Bożą i pamięć o Bożych darach: uczęszczanie do kościoła, nabożne słuchanie Słowa Bożego, częsta spowiedź sakramentalna i przyjmowanie Eucharystii, długie modlitwy, nawiedzanie ubogich, chorych i smutnych w domach i szpitalach, i usługiwanie im; ciekawe, że to ostatnie przedstawiono w opozycji do hojnej jałmużny, najwyraźniej niewystarczającej jako zbyt mało angażująca.

Spośród cnót okazanych w Nawiedzeniu na pierwszy plan wysuwa się oczywiście pokora. Wierni otrzymują w Marii, która, choć godna nawiedzenia Anioła, nie waha się nawiedzić matki sługi swego Syna, przykład pokory współbrzmiący z przykładem samego Jezusa, który przyjdzie po chrzest do Jana (Mt 3). Pokorze Maryi towarzyszy miłość bliźniego, widoczna w ochoczym współodczuwaniu szczęścia i podejmowaniu trudów, by nieść pomoc i wypełniać obowiązki. Szczególną uwagę przyciąga dziewicza skromność, przykład zwłaszcza dla panien. To m.in. z niej, twierdzi Wujek za Ambrożym, wynika słynny pośpiech, który wyznacza wzór publicznego zachowania młodej kobiety — powściągania ciekawości, unikania opuszczania domu, pokazywania się, zbędnych rozmów, kontaktów z mężczyznami. Kaznodzieja wymienia najważniejsze cnoty kobiety: wstyd, milczenie i unikanie bycia widzianą. Twierdzi, że spotkanie z mężczyzną musi pociągać za sobą uszczerbek i obrazę czystości kobiety, przynajmniej w wymiarze duchowym; nieporównywalnie większą szkodę czyni, uznawana za dzieło diabła, rozmowa czy bliskość cielesna. Bezpieczeństwo kobiecych skarbów (urody, czystości i dobrej sławy) może zagwarantować tylko rzadkie

28 Tekst kazania cytuję, nieznacznie modernizując ortografię i interpunkcję, za wydaniem: Jakub Wujek, Postilla katholicka mnieysza, ktora ma w sobie kazaniá na święta Pánny Maryey, Apostołow, Męczennikow, wyznawcow pánien y wdow świętych, ktorych świętá kościot zwykt obchodźić przez cáty rok wedtug náuki Kościota Świętego Chrześciańskiego Powszechnego, cz. 2, Kraków 1871, s. 984-993. 
opuszczanie domu, co mają potwierdzać egzempla biblijne: żony Uriasza (pokazawszy się Dawidowi, upadła, doprowadziła króla do grzechu, a męża do śmierci - 2 Sm 11), córki Jakuba Dyny (przyglądając się obyczajom, sprowokowała gwałt i ściągnęła na ojca i braci niebezpieczeństwo i rozlanie krwi — Rdz 34), pramatki Ewy (wdawszy się w rozmowę z wężem, doprowadziła do upadku ludzkości - Rdz 3) ${ }^{29}$. Cnota dziewicy ma zależeć, naucza Wujek za Kasjodorem, od sześciu czynników: umiarkowania w jedzeniu i piciu; unikania próżnowania (Syr $33,28)$; surowego odzienia; powściągliwości zmysłów, zwłaszcza wzroku i słuchu; rzadkiego i cnotliwego wypowiadania się; strzeżenia się okazji do zła: podejrzanych osób, miejsc i czasu. Maryja jako przykład doskonałej dziewicy nie próżnuje oddając się przyjemnościom i rozrywkom, ale spieszy do służby u pobożnych i sprawiedliwych krewnych; nie podąża za swym pragnieniem, ale za natchnieniem Ducha; czyni to za zgodą narzeczonego i w jego towarzystwie (jako oczywistą wykorzystuje się apokryficzną wersję wydarzeń, zgodnie z którą Józef towarzyszył Maryi, pielgrzymując do Jerozolimy na święto); idzie ze skromnym pośpiechem, kontemplując Boże cuda (to jak u Reja reminiscencja ewangelicznej frazy o zachowywaniu spraw w sercu — Łk 2, 19 i 2, 51). Interesujące, że opis pośpiesznej wędrówki z Postylli... mniejszej... w warstwie stylistycznej wyraźnie pobrzmiewa opisem z Postylli Reja: „A szła z prędkością i z kwapieniem, nie bawiąc się w drodze ani strojąc postawek, ale nabożnie rozmyślając w sercu dziwne sprawy Pańskie”. Jeszcze wyraźniej widać to w „dużej” Postylli... (skrót w ...mniejszej... nieco zatarł piętno zapożyczenia):

[...] idzie z pośpiechem a z skwapieniem, nic sie nie bawiąc po ulicach, nie chodząc w oględy, a nic sie nie dziwując, a nie strojąc postawek, to tam to sam, na każdą stronę nic nie poglądając, ale nabożnie rozmyślając w sercu swym dziwne sprawy Pańskie. ${ }^{30}$

29 Mizoginiczne nastawienie nie tylko prowadzi kaznodzieję do surowości wobec bohaterek, szczególnie rażącej w przypadku gwałtu, lecz także każe mu przemilczać biblijne obciążenie odpowiedzialnością mężczyzn. Por. także M. Kuran, Kobieta $w$ Postylli Jakuba Wujka. Ideat biblijny a rzeczywistość, w: Idee chrześcijańskie w życiu europejczyka. Język. Piśmiennictwo. Sztuki plastyczne. Obyczaje. Materiaty z konferencji 15-17 maja 2000 r., red. Z. Staszewska, A. Ceglińska, Łódź 2001, s. 219-230.

30 Tekst kazania cytuję, nieznacznie modernizując ortografię i interpunkcję, za wydaniem: Jakub Wujek, Postylle kátholiczney o swiętych część wtora letnia, w kthorey sie za- 
Refleksję nad skutkami wizyty Maryi w domu Zachariasza otwiera temat poruszenia się Jana jako znaku radosnego uczczenia Boga i Jego Matki. („Duża” Postylla... dopowiada, że tak wypełnia się obietnica dana ojcu Jana i że jej spełnienie to główny cel natchnionej wizyty Maryi). Mówi się o napełnieniu Elżbiety Duchem, przy czym ma je potwierdzać zbieżność słów o błogosławionej między niewiastami z pozdrowieniem Gabriela (Łk 1, 42 i 1, 28). Nie chodzi tu tylko o nadprzyrodzone źródło pozdrowienia; zasadniczy sens objawiają marginalia: „Ewangelikowie nie mają Ducha Bożego". Skoro słowa Pozdrowienia Anielskiego podczas Zwiastowania i Nawiedzenia pochodziły z Bożego natchnienia, odrzucenie ich funkcji modlitewnej przez protestantów jest znakiem, iż ich nauka i praktyka nie są z Ducha. Skrypturalne oskarżenie wskazuje na szatana i jego zazdrość o chwałę Marii jako źródło ewangelickiego zakazu modlitwy do Matki Bożej. Ci, którzy wyłamują się z powszechnego Jej błogosławienia (prorokowanego w Magnificat — Łk 1, 48), to „jaszczorcy narod i nasienie onego węża starego” — potomstwo szatana, którego nieprzyjaźń z Niewiastą i Jej Potomstwem zapowiedział Bóg w Protoewangelii $(\mathrm{Rdz} 3,15)$. W „dużej” Postylli... wywód ten kończy się optymistycznym przypomnieniem o klęsce diabła. Plemię szatańskie, które nie czci z Duchem Świętym, Aniołami, świętymi i wszystkimi narodami Maryi, jest identyfikowane jako „niezbożni kacerze”, którzy bluźnią Jej, negując Pozdrowienie Anielskie. Kaznodzieja z tęsknotą za dawnymi czasami chwali przodków, a zwłaszcza matki, które w dolegliwościach brzemienności i połogu modliły się za przyczyną Maryi. Jej pośrednictwo jest skuteczne jak w Nawiedzeniu, Wujek poucza więc kobiety, by naśladując Jej cnoty, gorliwie polecały się Jej opiece. Kazanie w „dużej” Postylli... kończy się nawet maryjną modlitwą pochwalno -błagalną z parafrazą słów Elżbiety (prośba o zbawienie kierowana jest jednak do Boga Trójjedynego). Znajduje się w niej wezwanie, by Maryja nawiedziła orantów, szczególnie w czasie śmierci; pragnienie usłyszenia Jej głosu, na który dusza się rozraduje i wyzwoli z więzienia ciała, wyrażono w języku Pieśni nad pieśniami, zgodnie z tradycją jej mariologicznej interpretacji. Maryja to Oblubienica o wdzięcznym i słodkim głosie oraz pięknym i radosnym obliczu (Pnp 2, 14). Refleksja o skutkach

wieraia kazania na Swiętha Panny Maryey, Apostotow, Męczennikow y innych świętych, ktorych święta Kościot zwykt obchodzić: poczq̨wszy od s. Iana Krzćiciela, aż do Adwentu, t. 2, cz. 2, Kraków 1868-1870, s. 554-570. 
Jej przybycia została też w „dużej” Postylli... uzupełniona pouczeniem o potrzebie docenienia dobrego gościa. Świecka pozornie nauka, że „Pozdrowienie człowieka dobrego ważne” i „Dobry gość błogosławieństwo w dom przynosi”, okazuje się istotna dla życia kościelnego po doprecyzowaniu, że chodzi zwłaszcza o stosunek do kapłanów ${ }^{31}$.

Błogosławieństwo Maryi tłumaczy kaznodzieja w Postylli... mniejszej... jako przywilej dziewiczego macierzyństwa - cudowną wolność od przekleństw braku potomstwa oraz bólu rodzenia i utraty dziewictwa zarazem. Mowa o wiecznym dziewictwie Maryi, ante partum, in partu i post partum. To wielkie obdarowanie nie czyni jednak Maryi największą — słowa o błogosławionym owocu żywota dają asumpt do przypomnienia o nieskończonej wyższości Syna Bożego, błogosławionego zawsze i wszędzie (Rz 9, 5). Interpretacja podąża w stronę kontrowersji dogmatycznych wokół Wcielenia. Kaznodzieja odrzuca teorie negujące pochodzenie natury ludzkiej Chrystusa od Maryi: doketyzm manichejczyków głoszących złudność i pozorność człowieczeństwa Jezusa; koncepcje walentynian o ciele pneumatycznym Jezusa, poczętego „poprez Maryję” i nie przyjmującego nic z Jej natury; monofizytyzm eutychian głoszących odmienność ludzko-Boskiej natury Jezusa od ludzkiej natury Maryi. Na marginaliach zamieszcza formuły ortodoksyjne o prawdziwości ludzkiej natury i Maryjnego synostwa Jezusa: „P<an> Chrystus przyjął prawdziwe nasze człowieczeństwo”, „P $<$ an $>$ Chrystus prawy Syn $\mathrm{P}<$ anny> Maryjej”, „P<an> Chrystus tejże natury co i my według człowieczeństwa”. Także interpretacja określenia „Matka Pana” zmierza w stronę kontrowersji dogmatycznej — odrzucenia herezji nestoriańskiej, która odbiera Maryi tytuł Theotokos, dowodząc, że pierwiastek Boski z ludzkim połączył się w Jezusie po narodzeniu, zaistniały więc w Nim dwie natury i dwie osoby. Wykład ortodoksyjny o dwóch naturach, Boskiej i ludzkiej, w jednej Osobie Syna Boga i Maryi oraz o Maryi — matce Boga-Człowieka — to broń nie tyle przeciw herezji historycznej, ile współczesnej: na marginesie Wujek zaznacza: „Tacyć są dziś Nowokrzczeńcy”, utożsamiając naukę Nestoriusza z teologią XVI-wiecznego anabaptyzmu ${ }^{32}$. Wujek podkre-

31 Por. J. Misurek, Jakub Wujek SJ. Teolog duchowości - Maryjny wymiar duchowości, w: Id., Historia i teologia polskiej duchowości katolickiej, t. 1 (w. X-XVII), Lublin 1994, s. 163.

32 W kazaniu z „dużej” Postylli... krytykuje też jego sztandarowy postulat chrztu dorosłych: skoro nienarodzony Jan został napełniony Duchem, to i dzieci mogą przyjąć chrzest, odmawianie im go to zabijanie dusz, czyn Heroda. 
Śla również, zgodnie z ówczesną antropologią, wyjątkowość Jezusa, który w przeciwieństwie do innych dzieci już od poczęcia jest żywym i pełnym człowiekiem z duszą i ciałem.

Spotkanie Maryi z Elżbietą pozwala poznać te treści teologiczno -dogmatyczne, a także wzorce zachowań, zwłaszcza dla kobiet. Uczy, jak powinny wyglądać powitania, odwiedziny, rozmowy, w których pożądane są: pokora, szacunek dla starszych, uznanie godności z Bożej łaski, przypisywanie czci i chwały Bogu zamiast sobie, brak słów zbędnych i złych, niegodnych żartów, obmów, świeckich pieśni. Przykład Marii i Elżbiety współbrzmi z nauką apostolską o budujących rozmowach bez nieprzyzwoitości (Ef 4, 29 i 5, 3-4). Ten ideał kontrastuje z rzeczywistością „Zbytków dzisiejszych” — wszeteczeństwa na chrzcinach, weselach, pokładzinach, podczas biesiad i spotkań (znamienne, że wymieniono te związane ze świętowaniem sakramentów, a więc bluźniercze) określa się jako gorsze od pogańskich. W „dużej” Postylli... Wujek zatrzymuje się dłużej na grzechach mowy („Mowy dzisiejsze nie chrześcijańskie"): zbędnych przysięgach, daremnym wzywaniu imienia Boga, powiedzeniach przywołujących diabła, obmowach (zwłaszcza u kobiet). Z ironiczną zjadliwością przedstawia niestateczne, bezwstydne i bezbożne spotkania przy alkoholu, pieśniach świeckich i tańcach, jako przeciwieństwo natchnienia Duchem. Tę krytykę obyczajów wymierza w obydwu kazaniach w adwersarzy konfesyjnych — ewangelicki postulat znajomości Pisma i udziału świeckich w dysputach teologicznych przeradza się w Postylli... mniejszej... w obraz dyskusji o Biblii przy piwie, bulwersujących tym bardziej, że biorą w nich udział kobiety. Przeciw ich prawu do aktywnego udziału w życiu Kościoła przytacza kaznodzieja dosłownie rozumiane pouczenia św. Pawła, który nakazuje kobietom milczenie i zakazuje publicznego nauczania (1 Tm 2, 12). W Postylli... „dużej” Wujek przypomina także zalecenie, by niewiasty uczyły się jedynie w domu od mężów (1 Kor 14, 34-35), oraz argument na rzecz poddania kobiety mężczyźnie — pierwszeństwo Adama w stworzeniu i Ewy w upadku (1 Tm 2, 11-14). Biblijny argument za tezą, że „niewiasty [...] już na wieki nie mogą być Doktorkami”, wymierza $\mathrm{w}$ protestantów dopuszczających kobiety do studiowania i przepowiadania Ewangelii; ewangeliczki traktuje z ironiczną pogardą i oburzeniem, przypisując im słabą umiejętność czytania, zarozumiałość i gorszenie mężczyzn. Według obydwu homilii, od niewłaściwego 
zachowania ma odwieść kobiety przykład Maryi, która, choć natchniona i świadoma Bożych tajemnic, skromnie nie objawiała tego ludziom, a w Ewangelii przemówiła tylko czterokrotnie, zawsze roztropnie, koniecznie i pożytecznie. „Duża” Postylla... precyzuje intencje Jej wypowiedzi: pytając Gabriela, kierowała się dziewiczą czystością (Łk 1, 34), odpowiadając mu — posłuszeństwem (Łk 1,38), śpiewając Magnificat — pragnieniem dziękczynienia i chwalenia Boga (Łk 1, 46-55), prosząc o cud w Kanie - litością i miłosierdziem (J 2, 3). Wujek podąża za tradycją teologii biblijnej, która licząc „słowa” Maryi, nie uwzględnia wypowiedzi skierowanych do dwunastoletniego Jezusa w świątyni Łk 2, 48 - oraz do służących w Kanie - J 2, 5. Po uprzednim zaleceniu milczenia niewiast kaznodzieja poczuwa się do uzasadnienia śmiałej i obszernej wypowiedzi teologicznej Marii w Magnificat. dotąd milcząca w dziewiczej skromności, przemówiła, aby złożyć dziękczynienie Bogu, poznawszy, że ujawnił innym fakt Wcielenia. „Duża” Postylla... przypomina bohaterki biblijne, które jak Maryja śpiewały Bożą chwałę: siostrę Mojżesza Marię (Wj 15, 20-21), Deborę (Sdz 5), matkę Samuela Annę (1 Sm 2, 1-10), Judytę (Jdt 16, 1-17); w przeciwieństwie do Reja, ustawiającego Maryję w podobnym szeregu bohaterek, podkreśla jednak Jej wyższość jako doskonalszej w mądrości, roztropności i mowie. „Krótki wykład pienia $\mathrm{P}<$ anny> Maryjej” w obydwu postyllach Wujka przedstawia schemat kompozycyjny Magnificat: uwielbienie i wychwalenie Boga, wysławienie Jego miłosierdzia i mocy — wobec Maryi i wobec wszystkich ludzi, wysławienie Jego sprawiedliwości i prawdy (pewności obietnic). W wypowiedzi Maryi, peryfrastycznej wobec biblijnej, kaznodzieja podkreśla, że wielbi Ona Boga nie tylko ustami, ale sercem, uniżenie wypiera się własnej zasługi i wszystko przypisuje miłosierdziu Boga, dzięki któremu zostanie otoczona chwałą. Moc Boża czyni w Niej wielkie cuda: dziewicze poczęcie i Boże macierzyństwo. Wraz z Bożą sprawiedliwością objawia się w ukorzeniu pyszałków, mocarzy i bogaczy, a wywyższeniu pokornych, nasyceniu pragnących sprawiedliwości i miłosierdzia. Boża prawda i miłosierdzie realizują się w spełnieniu obietnicy danej narodowi wybranemu. W materię Maryjnego hymnu wpleciono biblijne przykłady Bożego działania: historie wieży Babel (Rdz 11, 1-9) oraz Saula i Dawida (1 Sm 16-31), przy czym znów pojawia się odniesienie do współczesnych konfliktów wyznaniowych: Bóg i dziś miesza języki pysznych „heretyków”, naśladowców budowniczych 
bluźnierczej wieży; niewątpliwie ma Wujek na myśli niejednorodny, skonfliktowany wewnętrznie i wciąż rozłamujący się ewangelicyzm.

Zakończenie kazania w Postylli... mniejszej... wysuwa na pierwszy plan nie treści teologiczno-biblijne ani teologiczno-dogmatyczne, ale moralistyczno-parenetyczne: Maryja to wzór prawdziwie chrześcijańskich obyczajów. Postylla... „duża” w podsumowaniu eksponuje parenezę ukierunkowaną na kobiety, zwłaszcza młode i niezamężne. Matka Boża to dla nich punkt odniesienia (stylistycznie Rejowe przecież: „niech sie tu jako w źwierciedle przypatrują”), wzór godnych zachowań, rozmów, bojaźni Bożej, pokory i cnoty.

„Duża” Postylla ... jest od ...mniejszej ... bogatsza o dwa ważne tematy z początku homilii. Mają charakter erudycyjny, teologiczno-biblijny, a nie moralistyczny, nie dziwi więc ich usunięcie w wersji skróconej. Pierwszy to porównanie do biblijnej Judyty (Jdt), przedstawienie hiperboliczne w warstwie stylistycznej, idealizujące w moralnej, a odnoszące się do niepokalanego poczęcia i bezgrzeszności w perspektywie teologicznej. Maria to najdoskonalsza kobieta wszech czasów pod względem urody, cnoty, pokory, roztropności i mądrości mowy, prawości czynów i przede wszystkim - wyłącznego chwalenia Boga. Można tak o Niej powiedzieć pewniej niż Asyryjczycy o Judycie (Jdt 11, 20-21), przedstawionej explicite jako prefiguracja Matki Bożej (jak Judyta obcięła głowę Helofernesa, tak Maria zdeptała głowę węża). Zachwyt nad urodą Marii łączy się z refleksją o prawdziwym pięknie kobiety — zgodnie z interpretacją psalmu o córze królewskiej (Ps 45(44)) i nauką apostolską (1 P 3, 3-4) nie wynika ono z zewnętrznego ozdobienia ciała, ale $\mathrm{z}$ wewnętrznej harmonii, cnót z pokorą na czele. Znamienny jest kształt stylistyczny tej wypowiedzi, niewątpliwie zależny od Rejowego kazania na Nawiedzenie: obrazu Maryi śpieszącej w góry bez wypaczonej troski o prezencję oraz obrazu grzesznych córek Syjonu:

[...] ujźrzysz dziwną jej ozdobę nie w tym zwierzchnym a świeckim ubierze, nie w przyprawnych włosiech, nie w łańcuszkach ani w klenotkach, nie w forbotkach, w tkaniczkach, w brameczkach, w bryżykach ani w barwiczkach, ani w inszych błazeństwach, ani w kosztownych niepotrzebnych a potwornych strojach. 
Ironiczna formalnie wypowiedź o braku pychy w Maryi: „patrz, jako sie z tego chlubi, jako sie w pychę podnosi, iż skoro usłyszała od Anioła o tej łasce [...]” też ma źródło Rejowe („Słuchajże dalej, jako sie ta panna w pychę podniosła, gdy jej ona pani Elżbieta powiedziała przez Ducha ś<więtego> [...]"). Ze szkoły Reja pochodzi również na przykład styl przeciwstawienia pokory Maryi współczesnym chrześcijankom o pogańskich obyczajach.

Drugi motyw z „dużej” Postylli... odrębny od ...mniejszej... też ma charakter prefiguracji. Kazanie z 1573 roku rozpoczyna się (po perykopie dłuższej niż w 1580 roku, z całym Magnificat, a nie tylko pierwszymi wersetami) od przypomnienia biblijnej opowieści o sprowadzeniu Arki Przymierza (2 Sm 6), określonej jako „Figura Nawiedzenia Panny Maryjej”. Uznanie Arki za figurę Maryi ma tradycję w pismach Ojców Kościoła, tytuł „Arka Przymierza” włączono także do Litanii loretańskiej33. U Wujka czytamy pełny wykład proroctwa: bogato zdobiona „skrzynia święta”, zawierająca mannę, prowadzona przez lud, uwielbiana przez Dawida w podskokach tanecznych, zapowiadana z trąbami i zawiedziona na trzy miesiące do domu Obededoma, otoczonego dzięki niej błogosławieństwem Bożym - to zapowiedź Maryi jako przybytku Chleba żywego, prowadzonej przez Ducha, uwielbianej przez skaczącego Jana, ogłaszanej przez Elżbietę i przebywającej przez trzy miesiące w domu Zachariasza, obdarzonym dla Jej Syna i dla Niej błogosławieństwem, czyli natchnieniem Duchem Świętym. Wydarzenie starotestamentowe zwiastuje ewangeliczne Nawiedzenie i jego uobecnienie w roku liturgicznym w uroczystości Nawiedzenia NMP. To wydarzenie pełne radości, która przejawia się w pieśni Maryi, pozdrowieniu Elżbiety i skokach Jana, niesie jednak ze sobą przestrogę. W historii starotestamentowej źli zostali ukarani: Uzza, który niegodnie dotknął Arki — śmiercią, Mikal, która szydziła z tańca Dawida - niepłodnością. Mogą się więc obawiać kary ci, którzy uwłaczają bluźnierczo Matce Boskiej, odmawiają Jej czci, wyśmiewają święty Kościół powszechny za nabożeństwo ku Niej; dotknie ich przekleństwo duchowej niepłodności - braku owocu w dobrych uczynkach, a w konsekwencji śmierć - wycięcie niepłodnego drzewa zgodnie z zapowiedzią Ewangelii (Mt 3, 10 i 7, 19). Wyłączający się z Kościoła przez odrzucenie pobożności maryjnej to oczywiście

33 Por. D. A. Forstner, Świat symboliki chrześcijańskiej, przeł. i oprac. W. Zakrzewska, P. Pachciarek, R. Turzyński, Warszawa 1990, s. 388. 
ewangelicy — ich dotyczy groźba, zawarta w konsekwentnym odczytaniu figury wprowadzenia Arki jako Nawiedzenia Najświętszej Maryi Panny.

Piotr Skarga

Rozpoczynając kazanie $\mathrm{Na}$ dzień Nawiedzenia Elżbiety od Matki Bo$\dot{z} e j .$. . Skarga wyznacza na marginaliach kierunek interpretacji: „Conc. Basil. Sess. 43.”. Wskazuje jako kontekst ustalenia Soboru Bazylejskiego, rozpoczętego w 1431 roku dla rozwiązania problemu husytyzmu, przywrócenia pokoju między władcami chrześcijańskimi oraz reformy Kościoła; jego decyzja miała zasadnicze znaczenie dla rozwoju święta Nawiedzenia Najświętszej Marii Panny. Dość późno włączone do liturgii, wprowadzone do kalendarza franciszkańskiego przez starania św. Bonawentury i szerzej przyjęte wraz z franciszkańskim oficjum, uczynione świętem ogólnokościelnym $\mathrm{z}$ wigilią i oktawą z wdzięczności za zakończenie schizmy awiniońskiej za pontyfikatu Urbana VI — otrzymało nową oprawę właśnie na Soborze Bazylejskim w 1441 roku. Na sesji XLIII uchwalono:

\begin{abstract}
Ponieważ w tych dniach chrześcijaństwo zewsząd jest niepokojone i wszędzie szaleje wojna i rozdwojenie, tak że Kościół walczący na różny sposób doznaje ucisku, dlatego to święte zgromadzenie uważa za swój obowiązek, aby święto, nazywane Nawiedzeniem Najświętszej Maryi Dziewicy, obchodzono we wszystkich kościołach, by Matka Łaski, prawdziwie czczona przez pobożne serca, wyprosiła u swego Błogosławionego Syna swoim wstawiennictwem pojednanie i by tak pokój znów nastał wśród wiernych. ${ }^{34}$
\end{abstract}

Schizmatyckość soboru, na którym przyjęto dekret koncyliarny, decyzji o święcie nie podważyła (potwierdzili ją następni papieże, wprowadzając osobne oficjum i formularz mszalny dla święta) ${ }^{35}$. Nie przeszkodziła również jezuicie Piotrowi Skardze powołać się na uchwałę, zapewne w uznaniu aktualności przesłanek do obchodzenia święta: braku jedności i niepokoju w Kościele, potrzeby rozwiązania problemów heterodoksji i ortodoksyjnej reformy Kościoła. Również w homilii z Kazań na niedziele i święta... ta perspektywa jest ważna, gdy Skarga

34 Cyt. za: J. Drozd, Maryja w roku kościelnym, Kraków 1983, s. 174.

35 Zob. ibidem, s. 173-174. 
zapowiada, że jako pierwsze przedstawi „nauki do utwierdzenia prawdy katolickiej z tej Ewangelijej służące" ${ }^{36}$, czyli elementy interpretacji perykopy, które mogą służyć jako argumenty katolickie w kontrowersjach konfesyjnych.

Hagiograficzne ukierunkowanie Żywotów świętych... powoduje, że autor skupia się na bohaterach ewangelicznego wydarzenia. Tekst, nie homiletyczny, choć nazywa się kazaniem, stanowi rodzaj materiału do medytacji nad życiem świętych. Analiza rozpoczyna się od wskazania na osoby (zalecenie, by na początku medytacji „widzieć osoby (wzrokiem wyobraźni)" proponował w Ćwiczeniach duchownych ojciec zakonu Skargi - por. np. ĆD 106, 194³7): czwórkę „daleko od siebie różnych" ${ }^{38}$ świętych, która wyznacza kompozycję kazania, gdy Skarga zajmuje się kolejno naukami, związanymi z hierarchicznie uporządkowanymi postaciami: Jezusa, Matki Bożej, św. Jana Chrzciciela i św. Elżbiety. Wcześniej przedstawia istotę święta — to radość ze spotkania Maryi z Elżbietą, podczas którego wcielony Syn Boży jeszcze przed narodzeniem objawia Boską moc, rozpoczyna dzieło zbawienia i rozdawnictwo darów Ducha Świętego przez Matkę. Kaznodzieja dostrzega podobieństwa między kobiecymi bohaterkami sceny: nazywa je „przedziwnymi”, zwraca uwagę, że są świadome cudu poczęcia dzięki Bożej łasce, widzi w nich prorokinie pełne tajemnic Trójcy Świętej, rozmawiające o odkupieniu. Po paralelach czas na antytezy, wskazujące na znacznie większą godność Maryi jako: matki Pana, a nie sługi, dziewicy, a nie wyzwolonej z niepłodności mężatki, rozdawczyni, a nie tylko odbiorczyni Bożych łask. Marginalna formuła o Szafarce („Łaska Boża przez Maryję się podaje”) towarzyszy metaforze Marii jako źródła żywej wody i Elżbiety jako roli polanej deszczem.

36 Tekst kazania cytuję, nieznacznie modernizując ortografię i interpunkcję, za wydaniem: Piotr Skarga, Kazania na niedziele i święta catego roku, cz. 3 Kazania odświętne przez caty rok, Lwów 1884, s. 207-216.

37 Por. Św. Ignacy Loyola, Ćwiczenia duchowne, przeł. M. Bednarz SJ, rewizja przekładu J. Sieg SJ, Kraków 2010, s. 76, 125.

38 Tekst kazania cytuję, nieznacznie modernizując ortografię i interpunkcję, za wydaniem: Piotr Skarga, Żywoty świętych Starego i Nowego Zakonu na każdy dzień przez caty rok, wybrane z poważnych pisarzów i doktorów kościelnych, do których przydane sa niektóre duchowne obroki i nauki przeciwko kacerstwom, przytem kazania krótkie na te święta, które pewny dzień w miesiącu mają, Petersburg 1862 (reprint: Warszawa 1997), s. $5-8$. 
Pierwsza, bo związana z osobą Chrystusa nauka, dotyczy sposobu działania Boga: jeszcze w łonie Dziewicy nie zwlekał ze zbawieniem i jakby pośpiesznie powołał posłańca, który zapowie Go i poprowadzi do Niego wiernych. Tak rozwija się ewangeliczna wzmianka o pośpiechu Maryi: Jezus, który jest źródłem wszelkiego dobra, pobudza Maryję do pośpiesznego nawiedzenia Elżbiety. To owocuje „poświęceniem” i uwolnieniem Chrzciciela od grzechu pierworodnego już w łonie matki, by stał się godny swej roli; ten pogląd teologiczny głosi Skarga jako spełnienie proroctwa Izajasza (Iz 49, 1). Rozpoznanie Chrystusa przez Jana dokonało się, gdy usłyszał on głos Syna Bożego przez Jego Matkę. Jezus bowiem „w ciele i z żywota Matki” czyni dobro rodzinie Zachariasza i światu. Jego pośpiech w udzielaniu łaski to dla wiernych przykład do naśladowania, by nie zwlekali z przyjęciem łaski ani z miłością do Zbawiciela.

Podstawową naukę związaną z Matką Bożą sformułowano: „Łaska

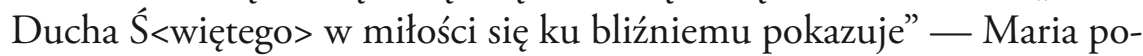
szła do krewnej z pociechą i posługą zamiast poprzestać na „bogomyślności”, czyli pobożnym skupieniu na sprawach Bożych, kontemplacji, i uczynek miłości objawił pełnię łaski. Miłość bliźniego bowiem, objawiona w czynnej posłudze, to skutek i znak Ducha Świętego w sercu. Skarga stale stara się jako źródło doskonałości Maryi ukazywać Boga, a obraz Maryi kształtuje jako przykład Bożego działania. Prezentuje zarazem, jak w innych hagiografiach (co uznawano za odzwierciedlenie ducha kontrreformacji), świętość jako postawę aktywną̧ ${ }^{39}$. Gorąca miłość Maryi przezwycięża wszelkie trudności: ciężar brzemienności, poczucie wyjątkowości, odległość, inne zajęcia, warunki górskiej podróży, konieczność wędrówki pieszej, osamotnienie, lęki młodej dziewczyny. Zarazem determinacja, by pomóc, nie powoduje postępowania wbrew przyjętym normom i dziewiczej skromności — lakoniczne sformułowanie Ewangelisty o pośpiechu Skarga rozwija (jak Rej czy powołujący się na Ambrożego Wujek) w obraz Maryi, unikającej po drodze ludzkich spojrzeń i spotkań, nieodpoczywającej w gospodzie, noc i dzień pośpiesznie zmierzającej do celu, chcąc sprostać ideałowi młodej dziewicy, której przystoi życie utajone w domu, a nie zbędne kontakty z ludźmi. Szczególną uwagę przyciąga pokora Marii, tak pożądana u młodych dziewic. Nie zważając na godność Matki Boga, Królowej Aniołów i Pani

39 Por. J. Ziomek, Renesans, Warszawa 1995, s. 404. 
wszechświata (najwyraźniej ma Ona być tych ról świadoma), poniża się, by jak niewolnica służyć staruszce o niższej godności; kaznodzieja modlitewnie uwielbia Jej pokorę.

Partie kazania o Janie i Elżbiecie dowodzą, że przez Maryję spływają na ludzi Boże dary, niesie Ona bowiem Jezusa. W homilii z Kazań... odnośnie do tego tematu użyto argumentu z Pisma oraz życiowego doświadczenia. Prawdę, którą objawia historia Nawiedzenia — że szczęście to owoc goszczenia sług Bożych - potwierdzają biblijne egzempla: pobyt Jakuba u Labana (Rdz 30) i Józefa w Egipcie (Rdz 39, 1-6), Eliasza (1 Król 17, 8-24) i Elizeusza w gościnie (2 Król 4, 8-37). W kazaniu z Żywotów... przypadek Jana ukazuje dary Boże jako cudowne, wykraczające poza ludzkie doświadczenie. Szereg sformułowań paradoksalnych, oksymoronicznych i antytetycznych obrazuje oddziaływanie głosu Marii - Jan w łonie matki otrzymał świadomość i rozpoznanie Boga, a przede wszystkim łaskę chrztu i obrzezania — uwolnienie od grzechu pierworodnego. W homilii z Kazań... Skarga mówi o obciążeniu wszystkich poczętych grzechem pierworodnym, a z nim - gniewem Bożym, skazaniem na potępienie, nędzą duszy i ciała, podleganiem śmierci (Ef 2, 2; Ps 51, 7). Przypomina wolność od grzechu Jezusa i Jego Matki, argumentując na rzecz niepokalanego poczęcia: Jezus, przyjmując ciało ludzkie wyłącznie od matki, nie chciał Jej skażenia. Przy okazji kaznodzieja eksponuje Maryjny przywilej bezgrzeszności, wolności od grzechu śmiertelnego i powszedniego (takie znaczenie ma epitet „przeczysta Matka”). Odnośnie do tematu „poświęcenia” Jana i chrztu sakramentalnego jako powszechnego sposobu uwolnienia od zmazy w homilii z Kazań... pojawia się też krytyka błędów „nowych mistrzów”, którzy nauczając o dzieciach, mających w sobie jak Jan Ducha i wiarę, osłabiają naukę o niezbędności chrztu. To zapewne dalekie echo nauczania Marcina Lutra. Twierdził on, że sakrament musi być przyjęty przez osobisty akt wiary, przeciw anabaptystom głosił ,fides infantium", czyli przekonanie o wierze niemowląt, argumentując m.in., że Jan podskoczył z radości na głos Marii ${ }^{40}$ (oczywiście intencją Lutra nie było podważanie znaczenia chrztu).

40 Por. A. Jagucki, Chrzest i nowe narodzenie w teologii ks. dr. Marcina Lutra, „Kalendarz Ewangelicki” 1984, s. 34; R. Mikler, Wyznanie o chrzcie w Konfesji Augsburskiej $i$ innych ksiegach symbolicznych, w: Z problemów Reformacji. 450-lecie Konfesji Augsburskiej i 400-lecie Księgi Zgody, red. nauk. M. Uglorz, Warszawa 1980, s. 83-95. 
W kazaniu z Żywotów... „poświęcony” Jan jest źródłem proroctwa matki, uświadamia Elżbiecie Boską naturę Dziecka Maryi. Sugestywny obraz nienarodzonego, niecierpliwego proroka, który śpieszy się, by oznajmiać Wcielenie i zbawienie - to obraz cudu Chrystusa uczynionego przez głos Matki. Dlatego passus o Janie kończy się niemal ekstatyczną modlitwą uwielbienia. Zwrot do ukochanej matki i opiekunki przyzywa Jej przybycia teraz i w godzinę śmierci. Jej głos ma oddziałać jak na Jana - jak on pragnie się wyrwać z ciemności łona, by ukazywać Światłość świata, tak wierni mogą spieszyć z ciemności świata do światłości wiecznej. To Jej słowa dzięki łasce Syna (Skarga stale podkreśla to pierwszeństwo dzieła Jezusa) mogą przeniknąć do wnętrza i obudzić obumarłą duszę jak Jana. Dlatego obecność Maryi jest dla Kościoła powszechnego szczęściem, jak Jej wizyta dla domu Zachariasza. Jest Ona „wszystką ozdobą” Kościoła, Królową Jeruzalem (obraz Kościoła jako nowej Jerozolimy). Podobnie jak Wujek przedstawia Ją Skarga jako Oblubienicę z Pieśni nad pieśniami o upragnionym słodkim głosie i pięknej twarzy (Pnp 2,14), wysławianą przez dziewczęta i królowe (Pnp 6, 8-9). Motyw działania Boga przez głos Maryi rozwija Skarga silniej w homilii z Kazań...: inwokacja do Matki Bożej zawiera tam prośbę o pomoc w nauczaniu, a argument za zwróceniem się do Niej stanowi wydarzenie ewangeliczne - skoro Jej głos pomógł Janowi prorokować, może pomóc kaznodziei w wysławianiu Jezusa i Jego Matki, pojmowanym jako działanie tożsame z Janowym ${ }^{41}$. Głos Marii ukazano jako nadzwyczajny sposób usprawiedliwienia (zamiast chrztu lub obrzezania), działanie Boga odstępującego od własnych praw (jak w: Joz 4, Joz 10, 12-14; 2 Król 6, 5-7; Dn 3; Wj 14).

Do części kazania z Żywotów... skoncentrowanej na Elżbiecie wprowadza modlitewna pochwała Maryi, Jej krewna jest bowiem przykładem wdzięcznego wysławienia Matki Boga i Szafarki łask. Skarga konsekwentnie przedstawia Elżbietę jako świadomą, dzięki działaniu Ducha, ukrytych sensów wydarzenia: ma ona prorocką wiedzę o Trójcy Świętej dokonującej Wcielenia, pojmuje, że wraz otrzymuje dary za pośrednictwem Maryi dzięki Jej udziałowi we Wcieleniu. W homilii z Kazań...

41 Zamykająca homilię podobna modlitwa nosi znamiona osobiste: Skarga błaga Maryję, która oddała go na służbę Bogu, aby uprosiła mu „poświęcenie” do posługi przygotowywania drogi Jezusowi i pozyskiwania dusz. Por. także S. Frankowski, Idea maryjna w życiu ks. P. Skargi, „Sodalis Marianus”, 1936, 35, s. 73-78; S. Nawrocki, Ks. Piotr Skarga jako czciciel Maryi, Kraków 1936, s. 32. 
Skarga zatrzymuje się dłużej na przeniknięciu przez Elżbietę tajemnic przeszłości, teraźniejszości i przyszłości. Cykl pytań retorycznych o źródło jej wiedzy o Zwiastowaniu i wierze Marii, Wcieleniu i Bożym macierzyństwie, spełnieniu Bożych obietnic danych Maryi służy wskazaniu na łaskę Boga, który uczynił starą, prostą kobietę mądrą, większą od proroków. Kaznodzieja wzywa, by zwłaszcza nauczający modlili się do Marii, aby, jak Elżbiecie, wybłagała im Ducha proroctwa i mądrość. Maryja okazuje się tu „skrzynią Bożą” pełną Boskich tajemnic, zawierającą Mądrość i Słowo, skarbnicą wszystkich nauk i zbawiennej wiedzy. Metafora ta uobecnia, kluczowe u Wujka, postrzeganie w Arce prefiguracji Matki Bożej. Temat mądrości Maryi rozwija się moralistycznie ${ }^{42}$ : przysłowia z ksiąg mądrościowych o potrzebie przyjaciół mądrych i pobożnych (Prz 13, 20; Syr 6, 36; Syr 13, 1) to wstęp do utyskiwania na współczesność, w której przez zadufanie, wstyd, złe towarzystwo rozmowa nie uczy, młodzi gardzą starymi, a nieuczeni uczonymi.

W kazaniu z Żywotów... Skarga kształtuje wypowiedź Elżbiety z interpretacji jej słów ewangelicznych („Tak się rozumieją one słowa Elżbiety starej”). Frazę o błogosławionej między niewiastami (Łk 1, 42) parafrazuje w rozbudowanej wypowiedzi o Maryi najszczęśliwszej z kobiet wszech czasów i określa przyczynę tego szczęścia jako noszenie w ciele Stwórcy i Władcy, ale i (zgodnie z Łk 1, 45) — wiarę, która przyjęła i dopuściła do realizacji nieprawdopodobną obietnicę Boga. Słowa o ruchu dziecka (Łk 1, 43-44) rozwija, mówiąc o Bożym darze dla Maryi - rozpoznaniu cudu Bożego macierzyństwa przez nienarodzonego proroka. Świadomość obdarowania, zbyt wielkiego w poczuciu Elżbiety, rodzi wdzięczność i chęć dziękczynienia, przy wiedzy, że nie może być ono wystarczające; jego wyrazem jest wysławienie „Panienki królewskiej”, sławy ludzkości, „ozdoby płci niewieściej” i pokory Maryi, która ukrywa swą godność.

O konieczności wysławienia Bożego macierzyństwa mówi Skarga, wykorzystując biblijny motyw wołających kamieni: „,synaczek mój czuje, coś ty zacz jest, i Duch Boży mnie objawia; a jeśli lud Boży tego nie zrozumie, kamienie mówić i sławić cię z owocu żywota twego będą”. To parafraza słów Jezusa z opisu wjazdu do Jerozolimy (Łk 19, 35-40), nawiązujących do proroctwa z Księgi Habakuka (Ha 2, 11) — fary-

42 Por. J. Misiurek, Chrześcijańskie życie duchowe w ujęciu Piotra Skargi SJ - Znaczenie kultu maryjnego, w: Id., op. cit., s. 198. 
zeusze, zgorszeni otaczaniem Jezusa chwałą jako Króla (Ps 118 (117), 26) otrzymują od Niego odpowiedź, ukazującą imperatyw świadczenia o Bożych, zbawczych dziełach i oddawania Bogu chwały ${ }^{43}$. Parafraza ukierunkowana mariologicznie oznacza więc imperatyw głoszenia chwały i oddawania czci Maryi, jest to bowiem w istocie chwalenie Boga za dzieło Wcielenia i Bożego macierzyństwa. Rozpoznanie odnośnie Marii, „coś ty zacz jest”, to rozpoznanie Jej „owocu żywota” — Jej godność to godność Matki Boga; to zasada oddawania Jej czci. W homilii z Kazań... imperatyw chwały Maryi opatrzony został warunkowym rzuceniem przekleństwa na siebie samego: „Niech język mój do ust moich przyschnie, jeśli cię kiedy zapomnię, najdroższa Dziewico, najpiękniejsza oblubienico Boga naszego, najpierwsza po Chrystusie pociecho i słodkości moja”. Sparafrazowano tu psalmiczną deklarację pamięci o Jerozolimie (Ps 137, 6), zmieniając adresatkę z Jeruzalem na określaną w języku Pieśni nad pieśniami Maryję̧ tów... konieczność sławienia Maryi kontrastuje z Jej pokorą. Podkreśleniu zaś współistnienia godności i pokory służy kontrast między Nią i Elżbietą. Skarga wkłada w usta Elżbiety dosadne słowa, które ukazują przepaść między nią — „niewolnicą” i „grzeszną babą” — a „prawdziwą i rodzoną Matką Boga”. Pokorę Marii podkreśla też Jej zachowanie jakby nieadekwatne wobec godności: usługiwanie Elżbiecie, które budzi zdumienie jako niestandardowe. Wychwalenie Maryi obejmuje rozpoznanie w Niej „drugiej Ewy” (zgodnie z paralelą ważną dla Ojców Kościoła $)^{45}$, która płodzi Sprawcę zbawienia. Kaznodzieja przywołuje też cytat biblijny współbrzmiący z pochwałą Maryi podczas Nawiedzenia — okrzyk na cześć Jezusa, w którym anonimowa kobieta nazwała szczęśliwymi łono i piersi Jego matki (Łk 11,27). Skarga przyznaje, że rozbudowana parafraza wypowiedzi Elżbiety ma ukazać wzór poprawnego chwalenia Maryi — ze wszystkich sił, nieustająco, w skoncentrowaniu na macierzyństwie Bożym — oraz wzór wdzięczności i dzięk-

43 Por. M. M. Kacprzak, „Niech kamienie wota... ”..., s. 94-107.

44 Nie jest zresztą w tradycji interpretacji nowością powiązanie: Maryja — Oblubienica Boga jako wcielenie Nowego Jeruzalem, profetyczna personifikacja Kościoła. Por. R. Skrzypczak, Wymiar maryjny Kościota. Maryja — model profetyczny Oblubienicy, w: Id., Kościót jako Niewiasta w relacji do Chrystusa swego Oblubieńca, Warszawa 2001, s. $156-161$.

45 Por. Ewa i Maria w historii zbawienia, w: H. Bourgeois, B. Sesboüé, P. Tihon, op. cit., s. 492-493. 
czynienia za Boże dobrodziejstwa. Kult maryjny zyskuje ostateczne potwierdzenie jako zgodny z wolą Chrystusa i tożsamy z Jego chwałą: „W niej Chrystus chce sławny być i w jej się czci kocha”. Boska wola stanowi też zasadę nadziei pokładanej w Pośredniczce przyczyniającej się do zbawienia.

A zatem część kazania poświęcona Chrystusowi ukazuje Jego działanie zbawcze w łonie Matki, przez Jej macierzyństwo — plasuje więc dogmat o Bożym macierzyństwie u podstaw rozważań o Niej; część o Maryi prezentuje Ją jako wzór miłości, czystości i pokory — skupia się więc na Jej osobistej doskonałości o źródle w Bogu; poświęcona Janowi mówi o łaskach otrzymywanych za sprawą Maryi - ukazuje Ją więc jako Szafarkę łask; skoncentrowana na Elżbiecie zaś przedstawia wzór chwalenia Matki Bożej — uzasadnia więc i projektuje konieczny i poprawny kult maryjny.

Kazanie nie wyczerpuje się jednak w analizie ukierunkowanej na czworo bohaterów. Kaznodzieja skupia się na najważniejszym — hymnie modlitewnym Marii. Zanim przemówi Ona: „Wielbij, duszo moja, Pana i rozradował się duch mój w Bogu Zbawicielu moim” (Łk 1, 4647), wypowiada słowa niebiblijne, nie tyle apokryficzne, co rozpoczynające retoryczną prezentację komentarza do Magnificat. Marię nazywa się nie tylko pokorną, ale i mądrą. Uznaje Ona pochwałę Elżbiety za słuszną, nie skażoną grzechem, błędem ani pochlebstwem. Oddaje swą chwałę Stwórcy jako źródłu swej godności. Jej pieśń ma nie tylko aspekt modlitewny, ale i dydaktyczny, przedstawia bowiem wzór modlitwy i pragnie do niej porwać („was ucząc, abyście ze mną tę pieśń śpiewali”). I porywa: kaznodzieja zwraca się do Marii z żarliwą deklaracją uwielbienia Boga Trójjedynego oraz ukierunkowania miłości i radości na Syna. W uwielbieniu Boga Maryja przewodzi i towarzyszy, inspiruje i zachęca. Dalsza interpretacja hymnu zawiera się w modlitwie — werset $Ł k$ 1, 48a wiedzie ku zestawieniu postawy Maryi i grzesznika, staje się okazją, by wymienić godności Maryi: bezgrzeszność, niepokalane poczęcie, wywyższenie nad aniołów i Boże macierzyństwo, mimo których uniżyła się Ona, co winno pobudzać do pokory. Parafraza słów z Łk 1, 48b otwiera pierwszy w tym kazaniu passus o czci Maryi, który explicite odnosi się do dyskusji konfesyjnych. Kaznodzieja znów z zapałem składa $\mathrm{w}$ imieniu wiernych deklaracje, tym razem odnośnie do wysławiania Matki Bożej: „Błogosławim my też ciebie, wynosimy i często Aniel- 
skiemi słowy pozdrawiamy”. Pytanie: „A kto ciebie nie sławi?” tylko pozornie jest retoryczne, bo otrzymuje odpowiedź; pozór retoryczności oddziałuje jednak w polemice: gdy wydaje się, że pytanie niesie sens: 'nie ma takich, którzy Cię nie sławią', informacja, że są, porusza, a odmawiających czci Maryi dyskredytuje, zwłaszcza wobec przypomnienia, że szanują Ją i poganie (chodzi zapewne o szacunek do Matki Jezusa w islamie $)^{46}$. Po słowach: „sam tylko niezbożny heretyk zajrzy sławie twojej, pozdrowienia się twego wstydzi, słyszeć twej chwały nie chce, bo w nim on wąż, któregoś ty głowę starła, ustawicznie z tobą walcząc, piętę twoją zranić usiłuje. Lecz my ciebie zawżdy sławiąc, prawowiernymi katolikami i tym Kościołem Syna twego ze wszystkich narodów zebranym, o którym ty prorokujesz, być pokazujemy”, wiadomo: „heretycy” to protestanci, którzy odrzucają kult maryjny, maryjną modlitwę z Pozdrowieniem Anielskim włącznie, pod hasłem chwały. Cześć Matki Bożej okazuje się znamieniem ortodoksyjności, przynależności do prawdziwego Kościoła, a takie jego pojmowanie sankcjonuje skrypturalnie proroctwo o błogosławieniu przez pokolenia (Łk 1, 48). Odmawianie czci Marii wynika z zazdrości, przedstawianej w perspektywie zapowiedzianej walki szatana z Bogiem $(\operatorname{Rdz} 3,15)$. Nie dziwi ta mariologiczna interpretacja Protoewangelii ani odwołanie do wersji tekstu z Wulgaty i przekładu Wujka, w której podmiotem zdania o zmiażdżeniu głowy węża jest Niewiasta, a nie Jej Potomstwo. Heretycka zazdrość protestantów o chwałę Maryi to zazdrość szatana. Kaznodzieja zanosi do Maryi (nie przypadkiem używa epitetu „przesławna” z rdzeniem jak w słowie „sławic”) modlitwę, by wspomogła w wysławianiu Jej samej. Niemal sentencjonalnie określa relację między chwałą Maryi i Boga — pierwsza pochodzi od drugiej i staje się nią: „wszystka na Syna twego Boga naszego z ciebie się obraca i tam się, skąd wyszła, wraca”. Jezuita nie jest takiej modlitwy pomysłodawcą, cytuje: „Dignare me laudare te Virgo sacrata, da mihi virtutem contra hostes tuos!" - końcowe wezwanie maryjne, dodawane w komplecie po Ave, Regina caelorum, antyfonie na okres od Oczyszczenia Matki Bożej (Gromnicznej) do Wielkiej Środy ${ }^{47}$, hymnie pochwalnym z błaganiem o pośrednictwo. Cytat współbrzmi

46 Por. Religia. Encyklopedia PWN, t. 3, Warszawa 2001, s. 519-520; M. M. Dziekan, Symbolika arabsko-muzutmańska. Maty stownik, Warszawa 1997, s. 62; M. i U. Tworuschka, Islam. Maty stownik, wyd. II popr. i poszerz., Warszawa 2005, s. 98-99. 47 Zob. Z. Janiec, Maryja w kulcie Kościota. Kazania i homilie maryjne, Sandomierz 2007, s. 5. 
z interpretacją Magnificat w kontekście Protoewangelii i różnic konfesyjnych: i tu pojawia się obraz wrogów Maryi, niewątpliwie tożsamych z „heretykami”. Przywołanie tej modlitwy z życia liturgicznego Kościoła ma zapewne potwierdzać, iż wychwalający Maryję to Kościół prawdziwy. W homilii z Kazań... ukazano i inny protestancki błąd mariologiczny: „ci ministrowie” „i żony swoje z najświętszą Matką Bożą równać śmieją". Traktowanie Maryi jako zwykłej kobiety jest dla oburzonego kaznodziei „bluźnierstwem” i „niewstydem”. Aby podkreślić niewspółmierność godności Maryi i protestantek oraz zdyskredytować ewangelicyzm, określa się ewangeliczki ekspresyjnie jako „sprosne niewieściska”. Skarga jak Wujek walczy z protestantyzmem przez krytykę jego wyznawczyń.

W parafrazie słów o „wielkich rzeczach” (Łk 1, 49a) z Żywotów... interpretuje szczególne obdarowanie Marii: to niespotykane w stworzeniu współistnienie dziewictwa i macierzyństwa, przy czym mówi się o dziewictwie ante partum, in partu i post partum ${ }^{48}$, a o macierzyństwie zgodnie z formułą o unii hipostatycznej ${ }^{49}$. Dogmat o Bożym macierzyństwie zatrzymuje dłużej uwagę Skargi w homilii z Kazań... Nagromadzenie wzniosłych epitetów na określenie Maryi realizuje w nim deklarację przypisania Jej wszelkich godności, które zamykają się w pojęciu Bożego macierzyństwa. Retoryczny dialog ze św. Elżbietą wymierzony zostaje w odradzające się w XVI wieku poglądy nestoriańskie. Krótki wykład o unii hipostatycznej w Jezusie: Jego prawdziwej Boskiej Osobie, Jego Boskiej naturze bez początku i końca oraz Jego prawdziwej naturze ludzkiej wziętej od Maryi — prowadzi do stwierdzenia prawdziwości Bożego macierzyństwa, wbrew herezji Nestoriusza, a zgodnie z rozstrzygnięciem Soboru w Efezie $(431 \text { rok })^{50}$. Musi pozostać niezrealizowane marzenie o wychwaleniu Marii w nowy sposób, gdyż nie ma tytułu większego niż „Matka Boga”.

W kazaniu z Żywotów... wychwalenie Bożych darów dla Maryi przechodzi w refleksję o obdarowaniu ludzkości, niewspółmiernym wobec Bożego macierzyństwa, ale ogromnym: to stworzenie, odkupienie,

48 Por. Maria, Matka Boga, zawsze Dziewica, s. 496-502.

49 Por. Sobór Efeski: Matka Boga, w: H. Bourgeois, B. Sesboüé, P. Tihon, op. cit., s. 494-496.

50 Por. I. Bieda, Chrystologia Ojców, w: Stownik wczesnochrześcijańskiego piśmiennictwa, oprac. J. M. Szymusiak, M. Starowieyski, Poznań 1971, s. 424-456; Sobór Efeski: Matka Boga, s. 494-496. 
przywiedzenie do pokuty i powołanie na drogę doskonałości chrześcijańskiej, obietnica wiecznego królowania z Maryją. Ciekawe stwierdzenie, że Bóg nawet „na koniec tytułem twym macierzyńskim, gdy wolę jego czynić będziemy, nas przyozdobić jest gotów”, to odwołanie do opowieści o odwiedzinach Maryi i krewnych u nauczającego Jezusa, które dały $\mathrm{Mu}$ asumpt do stwierdzenia, że pełniący wolę Jego Ojca są $\mathrm{Mu}$ bratem, siostrą i matką (Mt 12, 46-50). Niełatwy mariologicznie fragment Ewangelii z obrazem dość surowej relacji Jezusa wobec Marii wykorzystano dla podkreślenia, iż jest Ona wzorem posłuszeństwa woli Boga i zapowiedzią eschatologicznego wywyższenia. Zdaje się, że komentowane Magnificat staje się słowami uwielbienia kaznodziei, gdy mówi o miłosiernym i mocnym Bogu, łaskawym dla bojących się Pana (Łk 1, 49-50). Słowa o działaniu Boga, który upokarza pysznych i wywyższa pokornych (Łk 1, 51-52), spójnie z całym kazaniem interpretuje w odniesieniu do Bożych darów: pyszni przypisują je sobie, a nie Dawcy, pokorni — świadomi, że wszystko pochodzi od Boga, nie ufają swym możliwościom. Podobnie w homilii z Kazań... pokora jest łączona z użytkowaniem Bożych darów, gdy Skarga kontrastuje postawę Maryi z obyczajami współczesnymi: „białegłowy polskie” unoszą się pychą, każda chce okazać się najlepsza, jeśli chodzi o zewnętrzne przejawy godności: stan, strój, powóz i konie, służbę. Skarga postępuje dokładnie jak Rej: stosuje do nich cytaty z Księgi Izajasza o pysznych córach syjońskich i ich upadku (Iz 3, 16-24) i zwiastuje „hardym niewiastom”, że ich wzgarda dla rad apostolskich o strojach kobiecych (1 P 3, 3-5; 1 Tm 2, 9-10), pycha, do której pobudzają i mężów, zostanie ukarana. Kazanie z Żywotów... kończy się właśnie prośbą do Chrystusa o pokorę, która ma walor Jego naśladowania, ale stanowi też cechę Matki Bożej, i także dlatego Ona jest przywoływana jako pośredniczka. Znamienne, że mariologiczne kazanie o pośrednictwie i czci Matki Bożej, nasycone pełnymi uwielbienia epitetami (np. „miła Matka i Opiekunka”, „przedziwna Matka”, „przeczysta Panna”, „Panienka królewska”, „Królowa niebieska”, „Matka przesławna”) ${ }^{51}$, kończy się aklamacyjnym oddaniem chwały Chrystusowi.

51 Por. J. Rejowicz, Maryologja na ambonie skargowskiej, w: Piotr Skarga, Kazania o Przenajświętszej Bogarodzicy Niepokalanej Dziewicy, Kraków 1905, s. III-XIX; H. Haduch, Ks. Skarga a cześć Maryi, „Sodalis Marianus”, 1912, 11, s. 129-135; S. Okoniewski, Mariologia Skargi, „Sodalis Marianus”, 1919, 18, s. 106-110. 
Treści trzech XVI-wiecznych kazań na święto Nawiedzenia okazały się w dużej mierze zbieżne, aż zaskakująco zbieżne, jeśli chodzi o relację niewątpliwie ewangelickiego tekstu Reja wobec niewątpliwie kontrreformacyjnych tekstów Wujka i Skargi. To oczywiście wynik wspólnego zasadniczego źródła kazań — opowieści z Ewangelii Łukaszowej, a także akceptacji części wspólnej tradycji interpretacyjnej — Ojców Kościoła, np. św. Ambrożego. Już jednak ta oczywistość godzi w wyobrażenia stereotypowe: utwory katolickie, $\mathrm{w}$ nie mniejszym stopniu niż protestanckie, przypisują tekstowi biblijnemu niezaprzeczalne pierwszeństwo, rangę najwyższego autorytetu i funkcję najmocniejszego argumentu; sięgając do argumentów z tradycji, zwracają się w pierwszym rzędzie właśnie do Ojców Kościoła.

Zbieżność ta dotyczy również w niemałej mierze wykładu dogmatycznego, przy odmiennie rozłożonych akcentach: wbrew stereotypowym oczekiwaniom (choć przecież typowo dla refleksji protestanckiej w XVI wieku) utwór ewangelicki podkreśla Boże macierzyństwo Maryi, skupiając się na Jej roli we Wcieleniu, czyli pochodzeniu od Niej ludzkiej natury Chrystusa, pozostając w zgodzie z dogmatem o macierzyństwie Maryi wobec całej i jedynej Osoby Syna Bożego; eksponuje także wiarę w dziewicze poczęcie przez Maryję Syna Bożego i w dziewictwo jako Jej niezmienny stan. W dużej mierze tożsama jest ewangelicka i katolicka nauka moralna z perykopy o Nawiedzeniu: Maryja ze swym zachowaniem wobec Elżbiety i pieśnią pochwalną Magnificat, będąc przykładem działania miłosiernego i wszechmocnego Boga, jest wzorem do naśladowania dla każdego chrześcijanina — przede wszystkim w zakresie pokory, wiary (w większym stopniu dla ewangelików) i miłości bliźniego (w większym stopniu dla katolików) oraz doskonałego uwielbienia Boga, które wynika ze świadomości, że wszystko pochodzi od Niego - a także w sposób szczególny dla kobiet, głównie młodych panien - w zakresie skromności.

Nie sposób oprzeć się też wrażeniu bliskości literackiej i stylistycznej tekstów - dotyczy to przede wszystkim Reja i Wujka (Skargę najwyraźniej wiąże z Rejem wykorzystanie do krytyki obyczajów obrazu hardych niewiast z Księgi Izajasza; z pewnością zaś korzysta on z myśli Wujka, z którym zbieżności nie tłumaczą się wspólnymi źródłami) i nie jest zja- 
wiskiem nieznanym ${ }^{52}$, jednak odnalezienie niemal dosłownych cytatów w tożsamym kontekście weryfikuje proste wyobrażenie o katolickim kaznodziei piszącym przeciw Rejowi. Oczywiście to „przeciw” określa perspektywę utworów katolickich — kontrreformacyjnych — w stopniu zasadniczym. Protestanckie i Rejowe odrzucenie prawd o niepokalanym poczęciu, bezgrzeszności i wniebowzięciu Maryi, zjadliwy atak na katolicką obrzędowość świąt maryjnych i wreszcie — odrzucenie, wraz z wiarą w pośrednictwo, modlitwy maryjnej powodują, że wspólne przestaje się liczyć. Chciałoby się rzec, że Wujek i Skarga nie słuchają już Reja (choć zostawiają w kazaniach ślady jego lektury), gdy podkreśla nieporównywalną z niczym godność Bożej Matki, skoro usłyszeli już o bardzo niskim stanie Maryi; nie słyszą zaangażowanej duchowo i intelektualnie argumentacji przeciw formom kultu maryjnego i wywodu o należnej Matce Bożej czci, skoro zabrakło modlitwy do Niej. W polemice konfesyjnej nie czynią więc różnicy między herezją Nestoriusza, Walentyna, Eutychesa, współczesnymi anabaptystami oraz ewangelicyzmem augsburskim i reformowanym i wymierzają w przeciwników argumentację biblijną, odpowiadając pięknym za nadobne. Nie bacząc na wspólnotę moralistyki, ale mając w pamięci ostrość ataków adwersarzy, używają przeciw nim argumentów o charakterze obyczajowym, gdy atakują protestantki. Równocześnie w odpowiedzi na zarzuty ewangelickie z pietyzmem podkreślają pierwszeństwo łaski Chrystusa i nieporównywalną wyższość Jego godności wobec Maryjnej, która cała wynika z macierzyństwa Bożego. Zasadniczym punktem spornym, usuwającym wszystko inne w cień, pozostaje bowiem ważki temat Bożej chwały i Maryjnej czci; perykopa o Nawiedzeniu z uwielbieniem Maryi przez Elżbietę i hymnem Magnificat Maryi okazuje się dla tego sporu doskonałym punktem wyjścia.

Nieprawdziwy stereotyp ewangelickiej pogardy dla Matki Bożej rodzi się także z kazań Wujka i Skargi, jak m.in. z kazań Reja rodzi się stereotyp katolika stawiającego Marię w miejscu Chrystusa. Bo nawet jeśli pojawi się w czasach sporu umiarkowany i wyważony wykład pozytywny, w dyskusji polemicznej zostanie przemilczany jak niebyły.

52 Por. J. Ziomek, op. cit., s. 401; J. Starnawski, Postylla Wujka wobec Postylli Reja, w: Id., Pisarze jezuiccy w Polsce (wiek XVI-XIX). Studia i materiaty, Kraków 2007, s. 33-63. 


\section{From the Mariological reflection of the Reformation Period. Three Teachings on the day of Visitation of the Virgin Mary: Rej — Wujek — Skarga}

The article presents the interpretation of three sixteenth-century sermons on the celebration of the Visitation of the Virgin Mary: from Postylla by Mikołaj Rej (1556-1566), from Postilla katolickaj mniejszaj by Jakub Wujek (15791580) and from Żywoty swięte by Piotr Skarga (1579), also recalling the homilies on the day from the collection Postilla catholica by Wujek (1573) and from Kazania na niedziele i swięta by Skarga (1595). The article describes the teaching of a Protestant preacher and two Counter-Reformation preachers associated with the Mariological dogmas (especially the divine motherhood) and devotion to Mary (in the context of the discussion about the merits of the cult of Our Lady and manner of celebration of the Marian recollections) and monitors the moralistic content (universal and targeted at women) and shows the mutual relations of the texts.

Translated by Agnieszka White 